Article

\title{
Evolutionary Engineering of an Iron-Resistant Saccharomyces cerevisiae Mutant and Its Physiological and Molecular Characterization
}

\author{
Berrak Gülçin Balaban 1,2, Ülkü Yılmaz ${ }^{1,2}$, Ceren Alkım 1,2, Alican Topaloğlu 1,2, \\ Halil İbrahim Kisakesen 1,2, Can Holyavkin ${ }^{1,2}$ and Zeynep Petek Çakar 1,2,*(D) \\ 1 Department of Molecular Biology and Genetics, Faculty of Science \& Letters, Istanbul Technical University, \\ Maslak, Istanbul 34469, Turkey; berrakgb@gmail.com (B.G.B.); lkyilmaz@yahoo.com (Ü.Y.); \\ alkim.ceren@gmail.com (C.A.); topaloglual@gmail.com (A.T.); kisakesenhi@gmail.com (H.İ.K.); \\ holyavkin@gmail.com (C.H.) \\ 2 Dr. Orhan Öcalgiray Molecular Biology, Biotechnology and Genetics Research Center (ITU-MOBGAM), \\ Istanbul Technical University, Maslak, Istanbul 34469, Turkey \\ * Correspondence: cakarp@itu.edu.tr
}

Received: 30 September 2019; Accepted: 20 December 2019; Published: 24 December 2019

\begin{abstract}
Iron plays an essential role in all organisms and is involved in the structure of many biomolecules. It also regulates the Fenton reaction where highly reactive hydroxyl radicals occur. Iron is also important for microbial biodiversity, health and nutrition. Excessive iron levels can cause oxidative damage in cells. Saccharomyces cerevisiae evolved mechanisms to regulate its iron levels. To study the iron stress resistance in S. cerevisiae, evolutionary engineering was employed. The evolved iron stress-resistant mutant "M8FE" was analysed physiologically, transcriptomically and by whole genome re-sequencing. M8FE showed cross-resistance to other transition metals: cobalt, chromium and nickel and seemed to cope with the iron stress by both avoidance and sequestration strategies. PHO84, encoding the high-affinity phosphate transporter, was the most down-regulated gene in the mutant, and may be crucial in iron-resistance. M8FE had upregulated many oxidative stress response, reserve carbohydrate metabolism and mitophagy genes, while ribosome biogenesis genes were downregulated. As a possible result of the induced oxidative stress response genes, lower intracellular oxidation levels were observed. M8FE also had high trehalose and glycerol production levels. Genome re-sequencing analyses revealed several mutations associated with diverse cellular and metabolic processes, like cell division, phosphate-mediated signalling, cell wall integrity and multidrug transporters.
\end{abstract}

Keywords: oxidative stress; evolutionary engineering; stress resistance; Saccharomyces cerevisiae; transition metals; iron stress; $\mathrm{PHO} 84$; adaptive laboratory evolution

\section{Introduction}

After aluminium, iron is one of the most commonly found transition metals in the Earth's crust. In neutral environments, as well as in biological systems, iron is most often found in its $\mathrm{Fe}^{2+}$ (ferrous) and $\mathrm{Fe}^{3+}$ (ferric) oxidation states. Most forms of iron found in the environment are insoluble. This property of iron prevents biological systems from accessing this micronutrient. Salt forms are more soluble than other forms. Since the ferrous ion is much more soluble than the ferric ion in the $10^{-2} \mathrm{M}$ range, it is more toxic than the ferric ion. Ferrous iron is more bioavailable than ferric iron and it is favourable for oxidation to the more stable "ferric" form, which gains iron redox potential [1-3].

The redox potential range of $\mathrm{Fe}^{3+} / \mathrm{Fe}^{2+}$ can be changed between $-0.5 \mathrm{~V}$ and $+0.6 \mathrm{~V}$ depending on the physiological conditions and interactions with coordinating ligands. This redox range and reversible 
electron transfer potential make iron a crucial element in biological systems. Iron plays an important role in numerous reactions, such as oxygen transport (hemoglobin and myoglobin), electron transfer (cytochromes, catalases, ferredoxins) and DNA synthesis (ribonucleotide reductases) $[4,5]$.

While acknowledging the iron dependency of organisms, excess iron can, however, be toxic. Iron can generate highly reactive hydroxyl radicals via the Haber-Weiss-Fenton reactions. It is known that most of the hydrogen peroxide-related oxidative damage occurs with hydroxyl radicals produced by this reaction chain (see Equation (1)) [2]. The ROS (reactive oxygen species) which occur from this reaction can damage proteins, lipids (lipid peroxidation) and DNA (base modifications) [6,7].

$$
\begin{gathered}
\mathrm{Fe}^{2+}+\mathrm{O}_{2} \rightarrow \mathrm{Fe}^{3+}+\mathrm{O}_{2}^{-\bullet} \\
2 \mathrm{O}_{2}^{-\bullet}+2 \mathrm{H}^{+} \rightarrow \mathrm{H}_{2} \mathrm{O}_{2}+\mathrm{O}_{2} \\
\mathrm{Fe}^{2+}+\mathrm{H}_{2} \mathrm{O}_{2} \rightarrow \mathrm{OH}^{\bullet}+\mathrm{OH}^{-}+\mathrm{Fe}^{3+}
\end{gathered}
$$

Considering these properties of iron, it is critical that iron levels in an organism should be maintained at the base level while any excesses should be reduced.

Iron deficiency causes anaemia; however, excess iron may lead to kidney and liver damage (hemochromatosis). In addition, iron overload causes neurodegenerative disorders like Alzheimer's and Parkinson's disease. Additionally, some iron compounds are also suspected to be carcinogens [8].

Iron transport systems enable organisms to reach iron in a more controlled manner. Iron transport proteins, such as transferrin, maintain high levels of iron serum concentrations while protecting against toxicity of iron [3]. Thus, iron transport systems help overcome the low solubility problem of iron and prevent against toxicity [9].

Iron is also important for microbial biodiversity. The effect of metals on biofilm formation and biofilm resistance to toxic metals in terms of a time-dependent tolerance have been recently reviewed [10]. Very recently, a consensus statement on the key role and global importance of microorganisms in climate change biology has been published, where it was also mentioned that the ocean warming can alleviate the iron limitation of nitrogen-fixing bacteria, with critical potential effects on the new nitrogen supplied to food webs [11]. Considering the health and nutritional effects of iron, attempts were also made to prepare iron-enriched baker's yeast in recovery from dietary iron deficiency [12], or to investigate iron-related potential changes in the gut microbiota, such as characterization of the gut (Gallus gallus) microbiota upon consumption of an iron biofortified feed diet [13] and studying the effects of a decrease in iron bioavailability to human gut microbiome on the reduction of the growth of potentially pathogenic gut bacteria [14].

In order to keep iron levels balanced, organisms have evolved several mechanisms. In the basic eukaryotic model organism, Saccharomyces cerevisiae, iron is maintained by the help of two major iron uptake mechanisms: a high-affinity iron transport system and a low-affinity iron transport system [15]. Apart from these uptake mechanisms, S. cerevisiae copes with metal toxicity with the help of a sequestration strategy which involves intracellular chelating or compartmentalization into vacuoles [16].

S. cerevisiae is a great model organism to represent basic eukaryotes. The S. cerevisiae genome is compact and it is easier to manipulate and identify a gene in S. cerevisiae than in the human genome $[17,18]$. The homologous sequences, which usually show homologous functions, can also help reveal some unknown functions of biomolecules. For example, the genes that are responsible for transition metal homeostasis are highly conserved from yeasts to humans [8]. Smf1p, Smf2p and Smf3p are yeast membrane proteins responsible for the uptake of divalent metal ions (nickel, zinc, copper, cobalt and cadmium). The Nramp2 protein (natural resistance-associated macrophage protein), also called the Dct1 (Dmt1) protein, is a homologue of Smf1p and Smf2p (33-36\% identity in amino acid sequence) and it is responsible for metal ion transport in mammals [19]. The transmembrane protein Fre1p of S. cerevisiae is also homologous of the "Gp91" (Phox) protein of the NADPH oxidase complex 
(cytochrome b558) of human phagocytic cells [5]. Many examples can be given for the sequence homology of yeast cells to mammalian cells.

To gain insight into the iron stress resistance mechanism and understand the response of the basic eukaryote S. cerevisiae, evolutionary engineering, an inverse metabolic engineering strategy, has been applied in this study. Evolutionary engineering involves repeating cycles of mutations in the aim of obtaining the desired phenotype. Firstly, the reference strain was randomly mutagenized with the chemical mutagen ethyl methanesulfonate (EMS) and the iron stress was then applied systematically and continuously throughout the batch selection. Mutants selected from the final population were investigated. Eventually, one individual mutant with superior resistance properties was selected for further detailed analysis. Evolutionary engineering has been successfully used in our previous studies that involved a variety of stress types [20-27]. Using this strategy, an iron-resistant mutant has been obtained in the present study. The physiological, transcriptomic and genome re-sequencing properties of the iron-resistant mutant have been characterized. The transcriptome data of the mutant has attracted attention to genes other than the most widely-known iron homeostasis genes and genome re-sequencing data supported many of the findings.

\section{Materials and Methods}

\subsection{Strain, Media, Cultivation Conditions, Stress Factors}

The S. cerevisiae strain CEN.PK113-7D (MATa, MAL2-8c , SUC2) was kindly provided by Prof. Dr. Jean Marie François and Dr. Laurent Benbadis (University of Toulouse, France). Yeast minimal medium (YMM) containing 2.0\% (w/v) glucose (Sigma-Aldrich, Hamburg, Germany), 0.67\% (w/v) yeast nitrogen base) with $5.0 \mathrm{~g} / \mathrm{L}$ ammonium sulphate and without amino acids (Becton, Dickinson and Company, Sparks, MD, USA) and 2.0\% agar (Neogen Corporation, Lansing, MI, USA) for solid media were used for cultivations. Cultivations were performed at $30^{\circ} \mathrm{C}, 150 \mathrm{rpm}$ in an orbital shaker (Sartorius Certomat Göttingen, Germany), using $500 \mathrm{~mL}-2$ L Erlenmeyer flasks filled with YMM to 20\% of the flask volume. Optical density $\left(\mathrm{OD}_{600}\right)$ values were measured using a Shimadzu UV-1700 (Shimadzu, Tokyo, Japan) spectrophotometer. Two mL suspensions in 30\% (v/v) glycerol (MP Biomedicals, Solon, OH, USA) were used for preparing the $-80^{\circ} \mathrm{C}$ stock cultures.

\subsection{Evolutionary Engineering Protocol}

The reference strain CEN.PK113-7D, named as 905, was exposed to the chemical mutagen; ethyl methanesulfonate (Sigma-Aldrich, Hamburg, Germany) to obtain a randomly mutagenized initial culture named as 906, with increased genetic diversity, as described previously [28]. The mutagen allowed $10 \%$ of the initial culture to survive. Thus, this genetically diverse population was used as the initial culture in the selection experiments for iron-resistant mutants. The minimum inhibitory concentration (MIC) of iron that caused 50\% growth reduction was determined previously (Supplemental Figure S1), and $5 \mathrm{mM} \mathrm{FeCl}_{2}$ (Sigma-Aldrich, Hamburg, Germany), was applied as the initial, mild iron stress level of selection. For this purpose, 906 cultivated in YMM containing $5 \mathrm{mM} \mathrm{FeCl}_{2}$ was named as the first passage and upon cultivation for $24 \mathrm{~h}$, it was transferred to fresh medium containing a slightly higher $\mathrm{FeCl}_{2}$ stress level, as the next passage. For all passages of selection, a culture in $\mathrm{YMM}$ and without $\mathrm{FeCl}_{2}$ was grown in parallel as a control culture. In each successive passage, iron concentration was gradually increased and it finally reached up to $30 \mathrm{mM} \mathrm{FeCl}_{2}$ at the 15th passage. Survival was determined by dividing the $\mathrm{OD}_{600}$ value of the culture or passage grown with $\mathrm{FeCl}_{2}$ to that of the same culture grown under control conditions [21]. 


\subsection{Cross-Resistance Determination}

\subsubsection{Most Probable Number (MPN) Method}

MPN method estimates viable cell numbers in culture with $95 \%$ confidence [29]. To quantify stress resistance levels, MPN assay was performed in 96-well plates at $30^{\circ} \mathrm{C}$. Twenty microlitres of cultures with $\mathrm{OD}_{600}$ of $\sim 1.0$ were inoculated to five parallel wells containing $180 \mu \mathrm{L}$ YMM with and without (control) the stress factor, and then serially diluted by 10 -fold in each of the eight following rows. MPN scores were determined upon 48 and $72 \mathrm{~h}$ of incubation. Each score refers to the "number of organisms per unit volume" of the original sample and was calculated from the tables indicated (Lindquist) [30]. The survival rates of the cultures were calculated by taking the ratio of the number of cells/mL under stress condition to that of those under control conditions.

\subsubsection{Spot Assays}

Four $\mathrm{OD}_{600}$ unit of cells at an $\mathrm{OD}_{600}$ of $\sim 1.0$ were serially diluted up to $10^{-5}$ dilution, and $3 \mu \mathrm{L}$ were spotted on YMM-agar medium containing a variety of stress factors at a final concentration of $0.3 \mathrm{mM}$ $\mathrm{CuSO}_{4}$ (Sigma-Aldrich, Hamburg, Germany), 20 mM MnSO 4 (Sigma-Aldrich, Hamburg, Germany), $25 \mathrm{mM} \mathrm{MnCl} 2$ (Merck, Darmstadt, Germany), $10 \mathrm{mM} \mathrm{ZnCl} 2$ (Sigma-Aldrich, Hamburg, Germany), $2 \mathrm{mM} \mathrm{CrCl}_{3}$ (Acros organics, Geel, Belgium) , $25 \mathrm{mM} \mathrm{FeCl}$ (Sigma-Aldrich, Hamburg, Germany), $0.3 \mathrm{mM} \mathrm{NiCl}_{2}$ (Merck, Darmstadt, Germany), $2 \mathrm{mM} \mathrm{CoCl} 2$ (Sigma-Aldrich, Hamburg, Germany), $50 \mathrm{mM}\left(\mathrm{NH}_{4}\right)_{2} \mathrm{Fe}\left(\mathrm{SO}_{4}\right)_{2}$ (Merck, Darmstadt, Germany), $250 \mu \mathrm{M}$ bathophenanthroline sulphonate (BPS) (Alfa Aesar Karlsruhe, Germany), 0.5 mM H $\mathrm{O}_{2}$ (Merck, Darmstadt, Germany) and $2 \mathrm{~mL} / \mathrm{L}$ phenylethanol (Sigma-Aldrich, Hamburg, Germany). The plates were observed and photographed after incubation at $30^{\circ} \mathrm{C}$ for $48 \mathrm{~h}$.

\subsection{Physiological Analysis}

\subsubsection{Determination of Cellular Iron and Cobalt Contents}

Cellular iron contents were determined using a flame atomic absorption spectrometer (F-AAS) (AA 280 FS, Varian, Victoria, Australia). The wavelength and slit width values were $248.3 \mathrm{~nm}$ and $0.2 \mathrm{~nm}$, respectively. Air-acetylene flame was used. For measurements, $2 \mathrm{mM}\left(\mathrm{NH}_{4}\right)_{2} \mathrm{Fe}\left(\mathrm{SO}_{4}\right)_{2}$ which corresponds to $0.11 \mathrm{mg}$ Fe atom/mL was applied as the iron stress factor for $90 \mathrm{~min}$ at $30{ }^{\circ} \mathrm{C}$ and $150 \mathrm{rpm}$. The stress factor was then removed and the cells were dried at $80^{\circ} \mathrm{C}$. The measured cell dry weights for each triplicate sample were used to calculate $\mathrm{mg}$ Fe atoms/g cell dry weight values. Five millilitres of $10 \mathrm{M} \mathrm{HNO}_{3}$ (Sigma-Aldrich, Hamburg, Germany) was added to each $5 \mathrm{~mL}$ sample and incubated at $80{ }^{\circ} \mathrm{C}$ for cell lysis. After lysis, $10 \mathrm{~mL}$ distilled water was added to have a three-fold dilution prior to the F-AAS measurements. Iron contents were then calculated according to known standards. Cellular cobalt contents were also determined using the same procedure, with slight modifications: $2.5 \mathrm{mM}$ $\mathrm{CoCl}_{2}$ was used as the cobalt stress factor for $90 \mathrm{~min}$ at $30^{\circ} \mathrm{C}$. The wavelength and slit width values were $240.7 \mathrm{~nm}$ and $0.2 \mathrm{~nm}$, respectively.

\subsubsection{Extracellular Metabolite (Glucose, Ethanol, Acetate, Glycerol) Determination}

Growth physiological experiments in batch cultures and extracellular metabolite analyses were performed as described previously [23]. Cultures were grown both in the presence and absence of $15 \mathrm{mM}\left(\mathrm{NH}_{4}\right)_{2} \mathrm{Fe}\left(\mathrm{SO}_{4}\right)_{2}$ as the iron stress factor, which corresponds to $0.83 \mathrm{mg}$ Fe atom/mL.

\subsubsection{Reserve Carbohydrate (Glycogen, Trehalose) Determination}

A total of $25 \mathrm{OD}_{600}$ units of cells were harvested from each culture. One-millilitre aliquots were collected to calculate cell dry weight values at five different time points. The intracellular trehalose and glycogen content of the samples were determined in the presence and absence of $15 \mathrm{mM}\left(\mathrm{NH}_{4}\right)_{2} \mathrm{Fe}\left(\mathrm{SO}_{4}\right)_{2}$ as the iron stress factor, as described previously [23]. $\alpha, \alpha$-Trehalose glucohydrolase $\geq 1.0$ units/mg 
protein (Cat. No. T8778, Sigma-Aldrich, Hamburg, Germany) was used for the degradation of trehalose to glucose. Amyloglucosidase, 3500U (Cat. No. 11202367001, Sigma-Aldrich, Hamburg, Germany) was used for the degradation of glycogen to glucose.

\subsubsection{Oxidative Level Determination}

Determination of the Intracellular ROS Amounts by Fluorescent Intensity Measurements

A previously described protocol has been followed, with slight modifications [31]. Briefly, pre-cultures were cultivated until an $\mathrm{OD}_{600}$ of 1-1.2. Approximately, $1.4 \times 10^{8}$ cells were harvested and pre-incubated for $10 \mathrm{~min}$ at $30^{\circ} \mathrm{C} .2^{\prime}, 7^{\prime}$-Dichlorodihydrofluorescein diacetate (DCFH-DA) (Sigma-Aldrich, Hamburg, Germany) was applied for $30 \mathrm{~min}$. After probe penetration and washing, the pellet was re-suspended in $1000 \mu \mathrm{L}$ buffer. Vortexing cells with glass beads was repeated 10 times. The supernatant of the lysate was diluted by 10- or 20-fold to detect the fluorescence. Iron stress was applied before dye treatment to prevent $2^{\prime}, 7^{\prime}$-dichlorofluorescin $\left(\mathrm{DCFH}_{2}\right)$ oxidation by the stress factor.

\section{Lipid Peroxidation Assay}

Pre-cultures were cultivated until an $\mathrm{OD}_{600}$ of 1-1.2. Iron stress was applied throughout the cultivation. Approximately $1.4 \times 10^{8}$ cells were harvested, washed twice with $\mathrm{dH}_{2} \mathrm{O}$ and re-suspended in $1 \mathrm{~mL} \mathrm{dH_{2 }}$ O. As the starting material, $500 \mu \mathrm{L}$ of each sample were used. A previously described protocol has been followed [32].

\subsubsection{Lyticase Susceptibility Assay}

Lyticase susceptibility test was adapted from a previously described method [33]. Overnight cultures of the reference strain (905) and the iron-resistant mutant (M8FE) strain were cultivated in $50 \mathrm{~mL}$ YMM in $250 \mathrm{~mL}$-shake flasks by initiating from $0.2 \mathrm{OD}_{600}$ (approximately $2.8 \times 10^{6}$ cells $\mathrm{mL}^{-1}$ ), both in the presence and absence (control) of $15 \mathrm{mM}\left(\mathrm{NH}_{4}\right)_{2}(\mathrm{Fe})\left(\mathrm{SO}_{4}\right)_{2}$ stress and grown at $30^{\circ} \mathrm{C}$, $150 \mathrm{rpm}$ until stationary phase. The cultures were then harvested by centrifugation at $10,000 \mathrm{~g}$ for $10 \mathrm{~min}$ and an $\mathrm{OD}_{600}$ of $0.9 \mathrm{~mL}^{-1}$ cells were resuspended in $10 \mathrm{~mL}$ of $10 \mathrm{mM}$ Tris/HCl buffer ( $\mathrm{pH}$ 7.4) including $40 \mathrm{mM} \beta$-mercaptoethanol (Merck, Hohenbrunn, Germany). After the samples were incubated at $25^{\circ} \mathrm{C}$ for $30 \mathrm{~min}, 2 \mathrm{U} / \mathrm{mL}^{-1}$ lyticase (Sigma-Aldrich, St. Louis, MO, USA) was added into each sample and incubated at $30^{\circ} \mathrm{C}, 150 \mathrm{rpm}$. The lyticase susceptibility of the cells was monitored by measuring the decrease in $\mathrm{OD}_{600}$. The measured $\mathrm{OD}_{600}$ values were divided by the initial $\mathrm{OD}_{600}$ value and the ratio was multiplied by 100 to calculate the lyticase resistance. This test was performed as three biological repeats.

\subsection{Transcriptomic Analysis}

\subsubsection{One Colour DNA-Microarray Analysis}

For transcriptomic analysis, cultures were grown in the presence and absence of $15 \mathrm{mM}$ $\left(\mathrm{NH}_{4}\right)_{2} \mathrm{Fe}\left(\mathrm{SO}_{4}\right)_{2}$ as the iron stress factor. A previously described protocol has been followed, with slight modifications [23]. Briefly, RNA samples with a RIN value of $>9$ were chosen for microarray analysis and the obtained signals were normalized using the quantile technique. Signals detected by $100 \%$ in each probe set have been filtered. Probe sets were then filtered according to the coefficient of variations with a cut-off value of $50 \%$. Significantly changed expressions were acquired by moderated $t$-test with a $p$-value of $<0.05$. Entities were determined with a fold change cut-off value of 2.0, with 905 as the control condition. For significance analysis, the corrected $p$-value cut-off was chosen as 0.05 . Benjamini Hochberg correction was performed [34]. $p$-value computation was chosen as asymptotic (Agilent Technologies, Santa Clara, CA, USA). The complete microarray data are available at GEO repository under accession number GSE61317. 


\subsubsection{Microarray Validation by Quantitative RT-PCR (qRT-PCR) Analysis}

RNAs isolated for microarray analysis stored at $-80{ }^{\circ} \mathrm{C}$ were used for the qRT-PCR validation of the microarray results. Initial RNA concentrations were adjusted to $1 \mu \mathrm{g} / \mu \mathrm{L}$ for cDNA synthesis. Transcriptor High Fidelity cDNA Synthesis Kit (Cat. No. 05081955 001, Roche, Mannheim, Germany) was used for qRT-PCR and the kit protocol was followed. A total of $50 \mathrm{pmol} / \mu \mathrm{L}$ anchored-oligo(dT)18 primer was used for cDNA synthesis. A LightCycler 480 SYBR Green I Master kit (Cat. No. 04707 516 001, Roche, Mannheim, Germany) was used for qRT-PCR analysis (Roche LightCycler 480 II, Indianapolis, IN, USA). Gene expression results were normalized to that of the ACT1 gene ( $\beta$-actin, reference gene). The primer sets for selected genes with varying transcript abundance were designed by using the Primer-3-Plus assistance programme [35]. The reference strain (905, control) sample was used as the standard. The error rate of each run was smaller than 0.2 and efficiencies were between 1.8 and 2.2. The calculations were performed according to comparative CT method [36]. Average $2^{-\Delta C t}$ values were calculated from $\mathrm{CP}$ values obtained from three individual runs. Relative expression levels were calculated by normalizing $2^{-\Delta \Delta C t}$ values to that of the reference strain (905, control). Cycling conditions were as follows: denaturation for $10 \mathrm{~min}$ at $95^{\circ} \mathrm{C}$, followed by 45 cycles of $10 \mathrm{~s}$ at $95{ }^{\circ} \mathrm{C}$, $18 \mathrm{~s}$ at $56^{\circ} \mathrm{C}, 20 \mathrm{~s}$ at $72{ }^{\circ} \mathrm{C}$, and one cycle of melting for $5 \mathrm{~s}$ at $95^{\circ} \mathrm{C}, 1 \mathrm{~min}$ at $65^{\circ} \mathrm{C}$. The reaction was completed with denaturation at $40^{\circ} \mathrm{C}$ for $10 \mathrm{~s}$. For each run, melting curve analysis was performed to determine the reaction specificity.

For correlation, whole microarray sets were re-analysed by normalizing the data according to ACT1, using Genespring Software (Agilent Technologies, Santa Clara, CA, USA) and logarithmic fold-change values were used. For $r h o$ and $p$-values calculation, Kendall and Spearman tests $[37,38]$ were performed by using $\mathrm{R}$ software [39].

\subsection{Whole Genome Re-Sequencing}

Whole genome re-sequencing experiments were performed at Genext Biotechnology and Laboratory Services Ltd., as described previously [26]. The data of this work have been deposited in the NCBI Sequence Read Archive (SRA) under BioProject PRJNA575869.

\section{Results}

\subsection{Iron Resistance and Cross-Resistance of the Evolved Mutants to Other Transition Metals}

3.1.1. Selection of the Evolved Mutants from the Final Population and Their Metal-Stress Resistance Determination Using the MPN Method

The evolutionary engineering strategy consisted of successive batch selection in the presence of gradually increased iron stress levels, starting with $5 \mathrm{mM} \mathrm{FeCl}_{2}$ in the first passage, up to $30 \mathrm{mM}$ $\mathrm{FeCl}_{2}$ at the 15 th passage. As the survival rate of the 15 th passage was as low as 0.15 , the selection experiments were ended at this final population and the final population was plated on YMM-agar plates. Four individual colonies were randomly picked from the plates, upon incubation at $30^{\circ} \mathrm{C}$ for $48 \mathrm{~h}$. The selected mutants called M3FE, M5FE, M7FE and M8FE and the final population (FP) were cultivated in YMM containing $2 \mathrm{mM} \mathrm{CrCl}_{3}, 1 \mathrm{mM} \mathrm{MnCl}_{2}, 10 \mathrm{mM} \mathrm{FeCl}_{2}, 35 \mathrm{mM}\left(\mathrm{NH}_{4}\right)_{2} \mathrm{Fe}\left(\mathrm{SO}_{4}\right)_{2}, 1 \mathrm{mM}$ $\mathrm{CoCl}_{2}, 0.2 \mathrm{mM} \mathrm{NiCl}_{2}, 0.075 \mathrm{mM} \mathrm{CuCl}_{2}, 5 \mathrm{mM} \mathrm{ZnCl}_{2}$ stress factors and the viable cell numbers were determined using the MPN method. As we had also used chloride salts of other metals in our previous studies on evolutionary engineering of cobalt- [21] and nickel-resistant [23] S. cerevisiae, we have also used in this study $\mathrm{FeCl}_{2}$ during selection experiments. However, as $\left(\mathrm{NH}_{4}\right)_{2} \mathrm{Fe}\left(\mathrm{SO}_{4}\right)_{2}$ usually had a higher solubility than $\mathrm{FeCl}_{2}$, we also used it in the experiments of the present study. 
Survival rates as fold of the reference strain (905) are indicated in Figure 1. According to that, all selected mutants were resistant to $10 \mathrm{mM} \mathrm{FeCl}_{2}$ and $35 \mathrm{mM}\left(\mathrm{NH}_{4}\right)_{2} \mathrm{Fe}\left(\mathrm{SO}_{4}\right)_{2}$, as expected. Additionally, all mutants and FP showed cross-resistance to $1 \mathrm{mM} \mathrm{CoCl}$ and $0.2 \mathrm{mM} \mathrm{NiCl}_{2}$ stress and most of the mutants were cross-resistant to $2 \mathrm{mM} \mathrm{CrCl}_{3}$ and $1 \mathrm{mM} \mathrm{MnCl}_{2}$ stress. On the other hand, all mutants showed significant sensitivity to $5 \mathrm{mM} \mathrm{ZnCl}_{2}$ stress. Based on all these results, as the mutant with the highest resistance level in most of the stresses tested, M8FE was chosen for further detailed analyses.

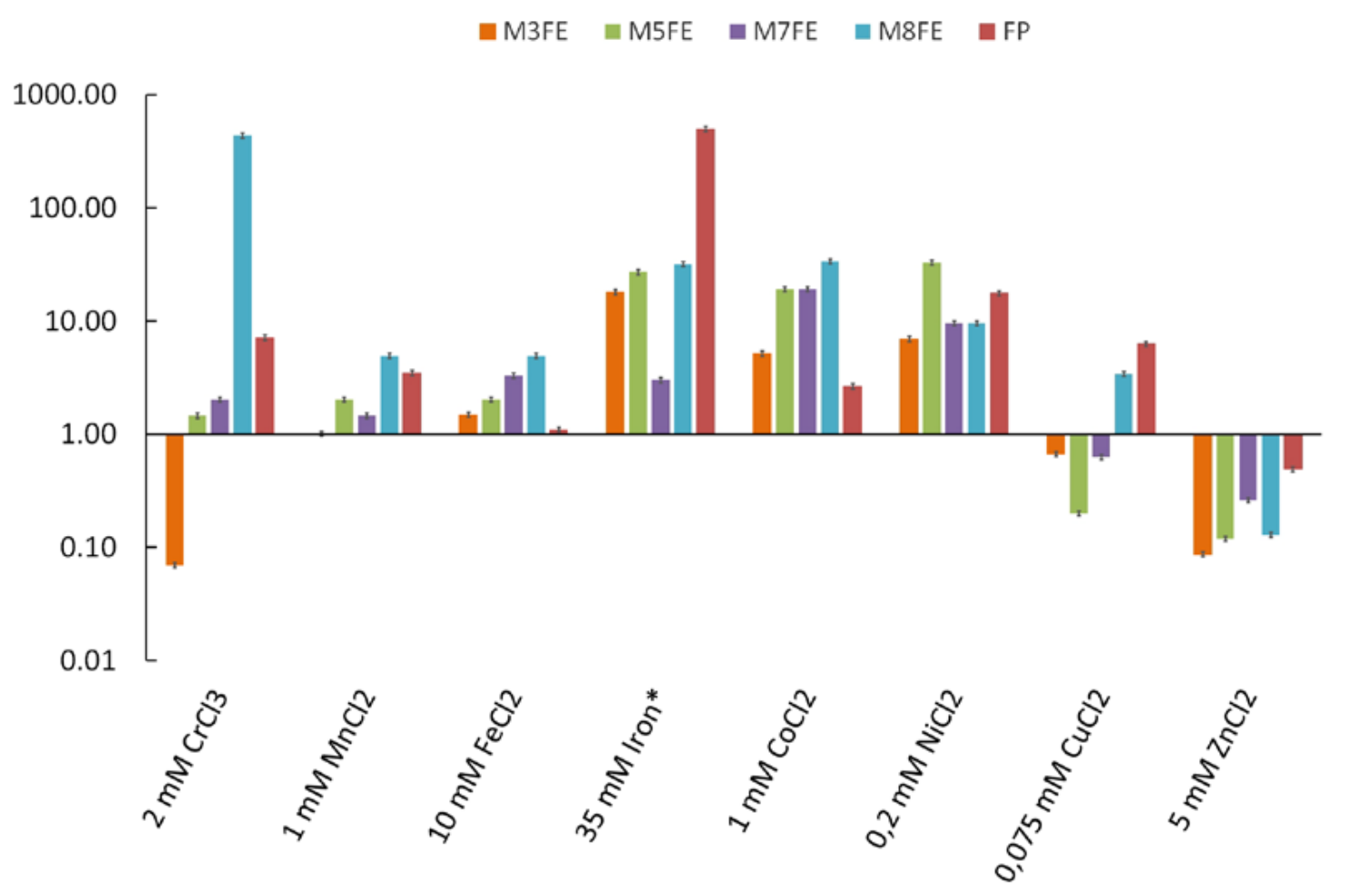

Figure 1. Survival rates as folds of the reference strain (905) of the mutants (M3FE, M5FE, M7FE, M8FE) and the final population (FP), represented in log-scale. The results were obtained using the MPN analysis under various metal stress conditions. Iron* indicates $\left(\mathrm{NH}_{4}\right)_{2} \mathrm{Fe}\left(\mathrm{SO}_{4}\right)_{2}$.

\subsubsection{Determination of Cross-Resistance to Metal and Non-Metal Stresses by Spot Assay}

Spot assays were performed for 905 and $M 8 F E$ under various stress conditions. In line with the MPN results, M8FE was resistant to $25 \mathrm{mM} \mathrm{FeCl}_{2}$ and $50 \mathrm{mM}\left(\mathrm{NH}_{4}\right)_{2} \mathrm{Fe}\left(\mathrm{SO}_{4}\right)_{2}$ stresses, compared to 905. As reported previously [9], iron remains bioavailable, even if it precipitates in solid media. Thus, the inhibitory effects of iron on solid media are more pronounced or reliable, compared to in liquid media. The high concentrations of $\mathrm{FeCl}_{2}(25 \mathrm{mM})$ and $\left(\mathrm{NH}_{3}\right)_{2} \mathrm{SO}_{4}(35 \mathrm{mM})$ used in solid media indicate a significant iron resistance level for $M 8 F E$.

M8FE also showed significant cross-resistance to $2 \mathrm{mM} \mathrm{CrCl}_{3}, 0.3 \mathrm{mM} \mathrm{NiCl}, 2 \mathrm{mM} \mathrm{CoCl}_{2}$ and $2 \mathrm{~mL} / \mathrm{L}$ phenylethanol. It was sensitive to $10 \mathrm{mM} \mathrm{ZnCl}_{2}$, compared to 905. M8FE did not display any significant resistance or sensitivity to an iron chelator ( $250 \mu \mathrm{M} B P S)$ or $0.5 \mathrm{mM} \mathrm{H}_{2} \mathrm{O}_{2}$ as a stress factor (Figure 2). 


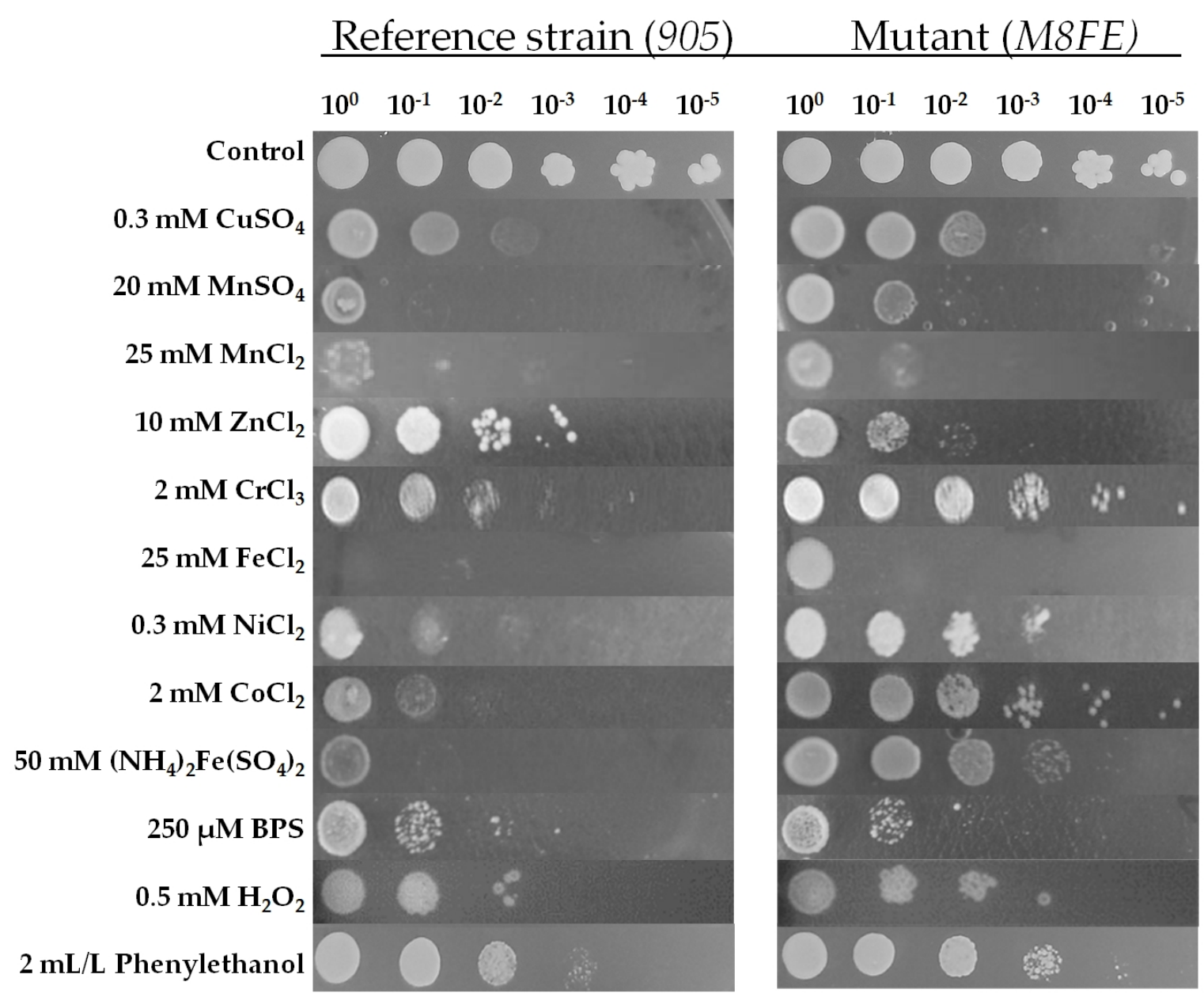

Figure 2. Spot assay profiles of 905 and M8FE under a variety of stress conditions. Dilutions are shown from $10^{0}$ to $10^{-5}$, from left to right.

\subsection{Physiological Analysis}

3.2.1. Iron and Cobalt Contents Determined by Flame-Atomic Absorption Spectrometry (F-AAS) Measurements

To gain insight into the iron resistance mechanism of $M 8 F E$ (e.g., sequestration, avoidance, or both), iron atoms arrested in M8FE and 905 were analysed by calculating the "mg Fe atom/g cdw" values obtained from the F-AAS analysis (Table 1). M8FE grown in YMM without iron (control group) contained high levels of iron, according to the F-AAS readings, indicating that M8FE already arrested iron atoms in or on itself, during the evolutionary engineering selection steps. After subtracting the control condition read values from the stress condition read values of each sample it was observed that the reference strain (905) took up more iron than M8FE. M8FE apparently avoided iron uptake more than 905 did and, even under non-stress conditions, M8FE already contained high levels of iron. Similar results were also obtained in the presence of cobalt stress, where the reference strain took up more cobalt than M8FE (Supplemental Table S1).

\subsubsection{Growth Behaviour and Extracellular Metabolite Profiles (Glucose, Ethanol, Acetate, Glycerol)}

The growth physiology of M8FE and 905 was investigated in batch cultures, in the presence and absence of $15 \mathrm{mM}\left(\mathrm{NH}_{4}\right)_{2} \mathrm{Fe}\left(\mathrm{SO}_{4}\right)_{2}$ stress. The growth profiles are shown in Figure 3. It was observed that the presence of iron stress in the culture environment significantly reduced the growth of 905 , while MSFE was apparently not affected by that iron stress. Additionally, there were no significant 
differences between the growth behaviours of 905 and M8FE under control conditions, implying that the evolved strain does not have any growth deficiency. The maximum specific growth rates $\left(\mu_{\max }\right)$ of the reference strain and M8FE under control conditions and M8FE under iron stress condition were all about $0.2 \mathrm{~h}^{-1}$. However, the $\mu_{\max }$ of the reference strain under iron stress condition was about $0.1 \mathrm{~h}^{-1}$, indicating the strong inhibition of the reference strain by the iron stress.

Table 1. Iron contents of M8FE and 905.

\begin{tabular}{|c|c|c|c|c|c|}
\hline & & $\begin{array}{l}\text { Read Values from } \\
\text { F-AAS Multiplied by } \\
\text { the Dilution Factor }\end{array}$ & $\begin{array}{l}\text { Read Values from F-AAS Multiplied by the } \\
\text { Dilution Factor-Controls Subtracted } \\
(\mathrm{mg} / \mathrm{L})\end{array}$ & $\begin{array}{l}\text { Cell Dry Weight } \\
(\mathrm{CDW}) / \mathrm{L} \\
(\mathrm{mg} / \mathrm{L})\end{array}$ & $\begin{array}{l}\text { Average } \\
\text { mg Fe/g cdw } \\
\text { Values }\end{array}$ \\
\hline \multirow{4}{*}{905} & \multirow{3}{*}{ Control } & 0.085 & & 1330 & \\
\hline & & 0.094 & & 1170 & \\
\hline & & 0.082 & & 1270 & \\
\hline & Iron stress & 0.750 & 0.663 & 1110 & $0.5942 \pm 0.0103$ \\
\hline \multirow{4}{*}{ M8FE } & \multirow{3}{*}{ Control } & 2.909 & & 970 & \\
\hline & & 2.974 & & 1030 & \\
\hline & & 2.996 & & 940 & \\
\hline & Iron stress & 3.261 & 0.302 & 940 & $0.382 \pm 0.088$ \\
\hline
\end{tabular}

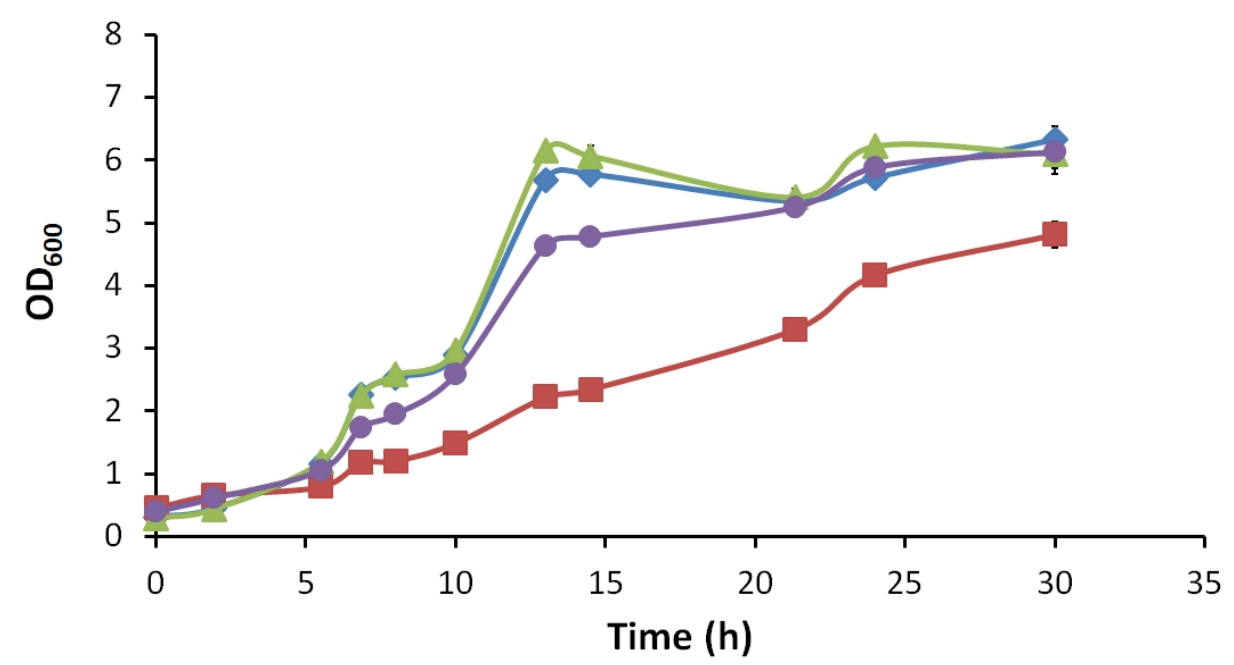

Figure 3. Growth profiles of 905 and M8FE in the absence and presence of $15 \mathrm{mM}\left(\mathrm{NH}_{4}\right)_{2} \mathrm{Fe}\left(\mathrm{SO}_{4}\right)_{2}$ stress. - 905 under control condition, 905 under iron stress condition, $\triangle$ M8FE under control condition, M8FE under iron stress condition.

In line with the growth profiles, glucose consumption, ethanol, acetate and glycerol production profiles were also obtained (Figure 4).

Interestingly, M8FE grown in the presence of iron stress produced significantly higher amounts of glycerol than all other cultures. Additionally, even in the absence of iron stress; M8FE still produced more glycerol than 905 (Figure 4). It was also observed that the presence of iron stress generally reduced the acetate levels, but increased the final glycerol levels of both 905 and M8FE. 


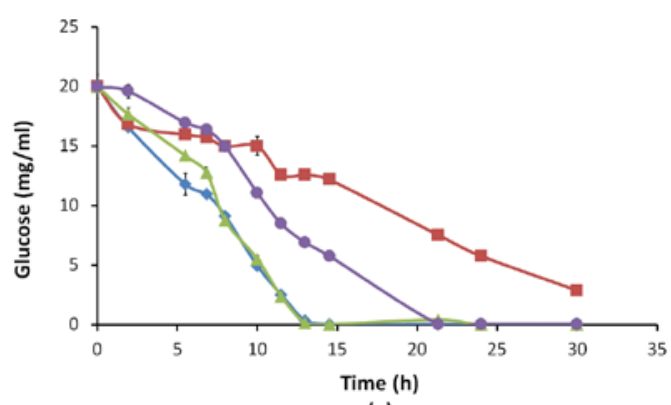

(a)

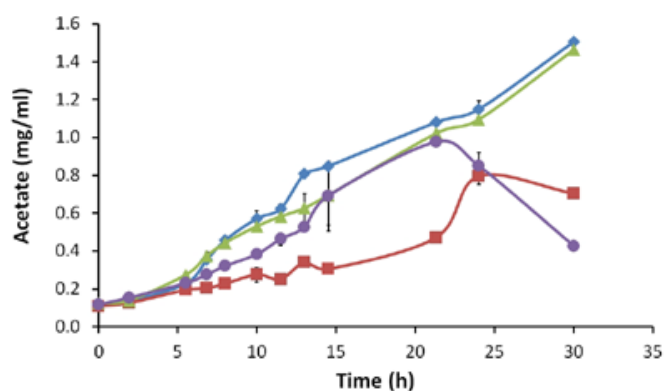

(c)

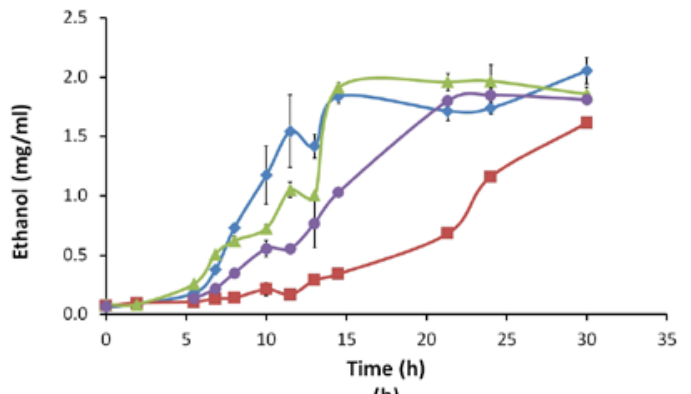

(b)

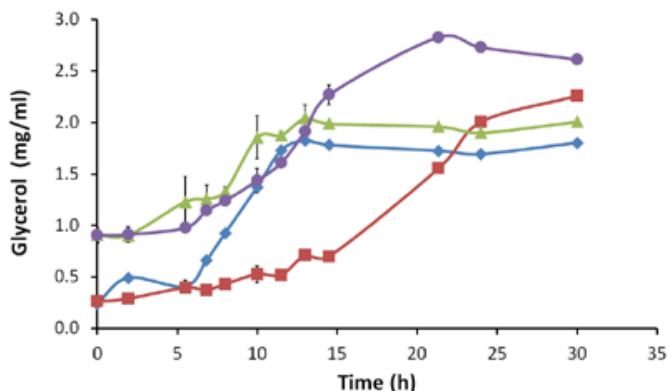

(d)

Figure 4. Average glucose (a), ethanol (b), acetate (c) and glycerol (d) concentrations $(\mathrm{mg} / \mathrm{mL})$ of 905 and M8FE in the absence and presence of iron stress ( $\$ 905$ under control condition, $\square 905$ under iron stress condition, $\triangle M 8 F E$ under control condition, $\bullet$ M $8 F E$ under iron stress condition).

\subsubsection{Reserve Carbohydrate (Trehalose, Glycogen) Profiles}

It is known that microorganisms produce reserve carbohydrates like trehalose and glycogen under stress conditions. Additionally, trehalose is also known to play a role in stress protection [40]. The relationship between iron stress and trehalose/glycogen reserves was investigated by enzymatic assays. Trehalose and glycogen contents per cell dry weights are shown in Figure 5.

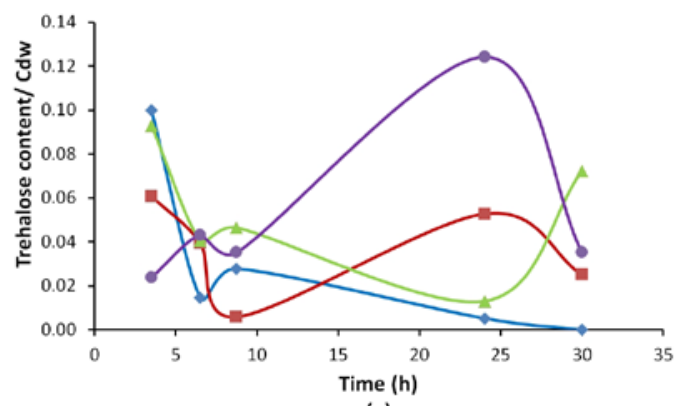

(a)

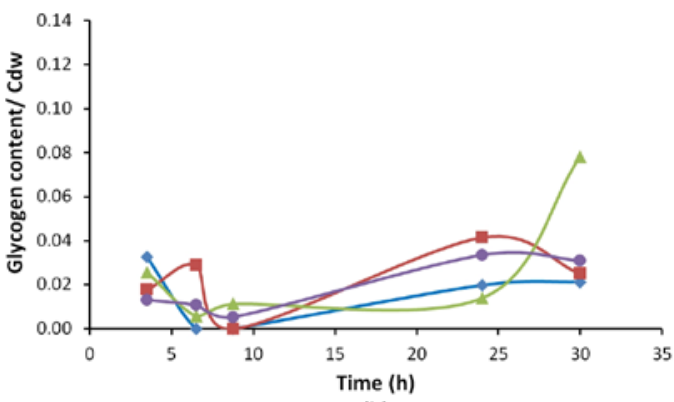

(b)

Figure 5. Trehalose (a) and glycogen (b) contents of M8FE and 905 (mg/mg) under control and iron stress conditions ( $\$ 905$ under control condition, 905 under iron stress condition, $\triangle$ M8FE under control condition, $\triangle \mathrm{M} 8 \mathrm{FE}$ under iron stress condition).

It was observed that the trehalose content of M8FE grown in the presence of iron stress was the highest, compared to all other cultures. However, after $25 \mathrm{~h}$ of cultivation, M8FE started to consume trehalose in the presence of iron stress (Figure 5). 


\subsubsection{Oxidative Level Determination}

Intracellular Reactive Oxygen Species (ROS) Amounts Determined by Fluorescent Intensity Measurements

Intracellular ROS amounts of M8FE and 905 in the presence and absence of iron stress are indicated as fluorescent intensities in Figure 6.

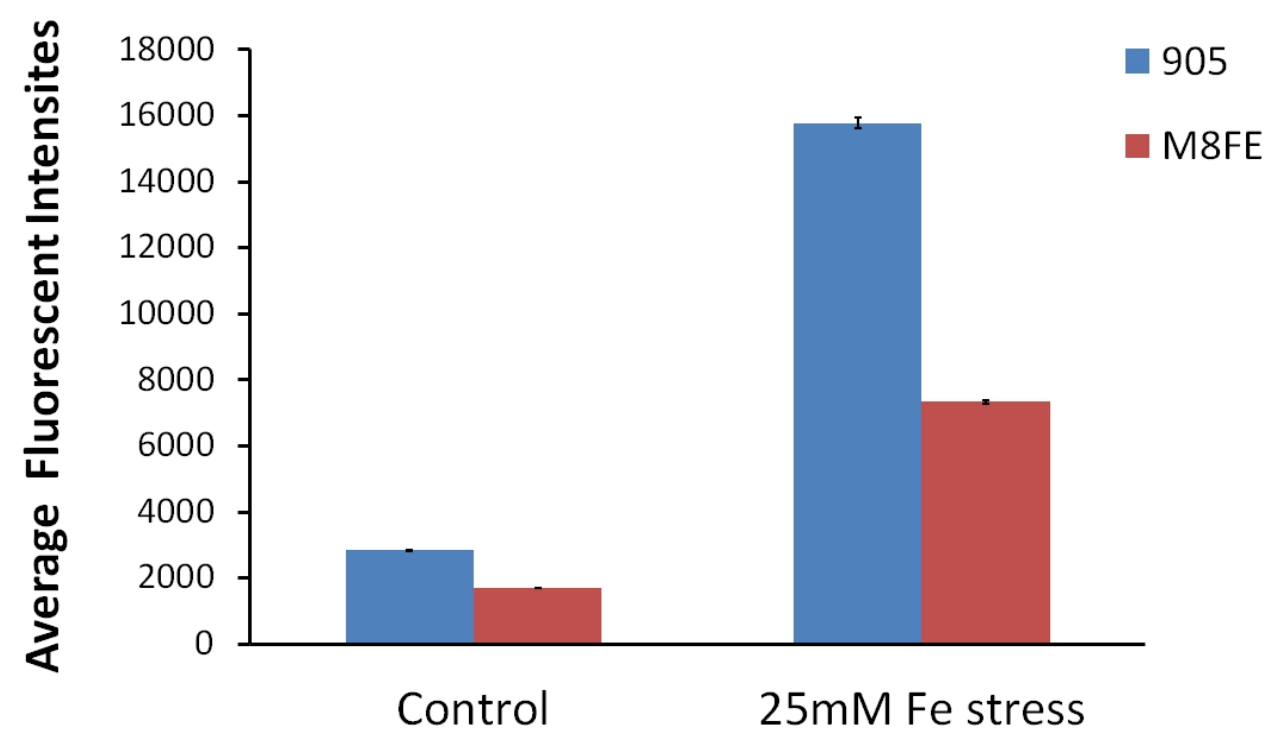

Figure 6. Fluorescent intensity values that indicate the ROS amounts of M8FE and 905 under control and iron stress conditions.

According to dichlorofluorescein (DCF) fluorescence intensities; ROS content of the mutant was 0.6-fold of that of the reference strain under control conditions, while it was only 0.4 -fold of it under iron stress conditions. The presence of iron stress significantly increased the intracellular ROS amounts in both M8FE and 905. However, both in the presence and absence of the iron stress, M8FE had lower ROS amounts than 905, implying that the mutant was able to cope with oxidative stress under both conditions.

\section{Lipid Peroxidation Assay}

Lipid peroxidation assay was employed to determine the oxidative degradation amount of lipids in the cell, an indirect indicator of ROS amounts.

Absorbance at $535 \mathrm{~nm}$ multiplied by the molar extinction coefficient of malondialdehyde (MDA)-thiobarbituric chromophore $\left(1.56 \times 10^{5} \mathrm{M}^{-1} \mathrm{~cm}^{-1}\right)$ indicated nmols of thiobarbituric acid reactive substances (TBARS)/mg protein (Figure 7). It was found that the mutant strain had significantly lower TBARS levels than the reference strain, in the presence of iron stress.

TBARS levels were higher under iron stress conditions for both strains and 0.75-fold of the reference strain in the iron-resistant mutant. According to both oxidative level determination experiments, M8FE can apparently cope with oxidative stress better than 905 . Thus, it can be expected that the mutant reduces the high intracellular oxidative levels by producing antioxidant elements. 


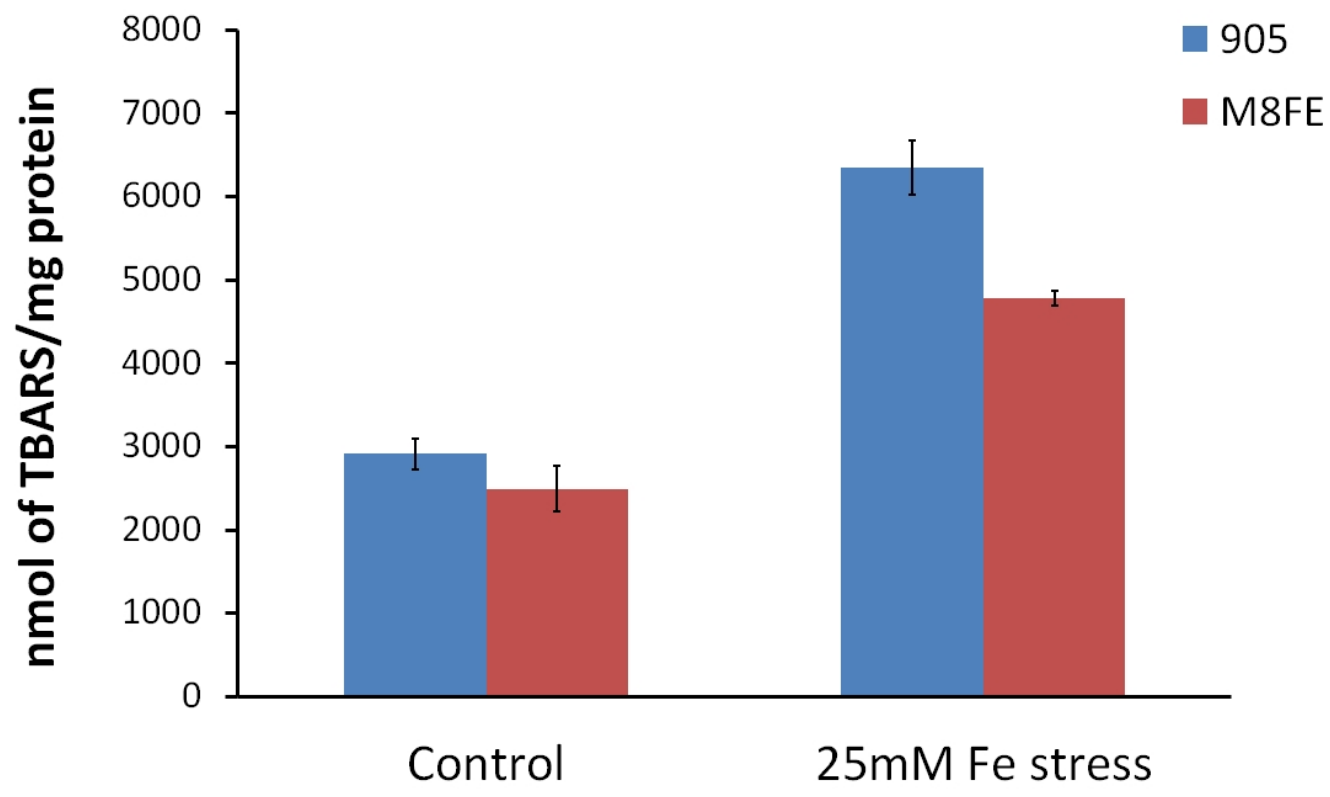

Figure 7. nmol TBARS/mg protein values of M8FE and 905, under control and iron stress conditions.

\subsubsection{Lyticase Susceptibility Assay}

Lyticase susceptibility assay was performed to evaluate the cell wall integrity of M8FE and the reference strain. The results showed that the M8FE mutant was significantly more resistant to the lyticase stress than the reference strain, particularly in the presence of $15 \mathrm{mM}\left(\mathrm{NH}_{4}\right)_{2}(\mathrm{Fe})\left(\mathrm{SO}_{4}\right)_{2}$ stress in the medium. Under non-stress conditions, both strains had comparable lyticase resistance levels. Additionally, the presence of iron stress in the culture medium increased the lyticase resistance of both strains (Figure 8).

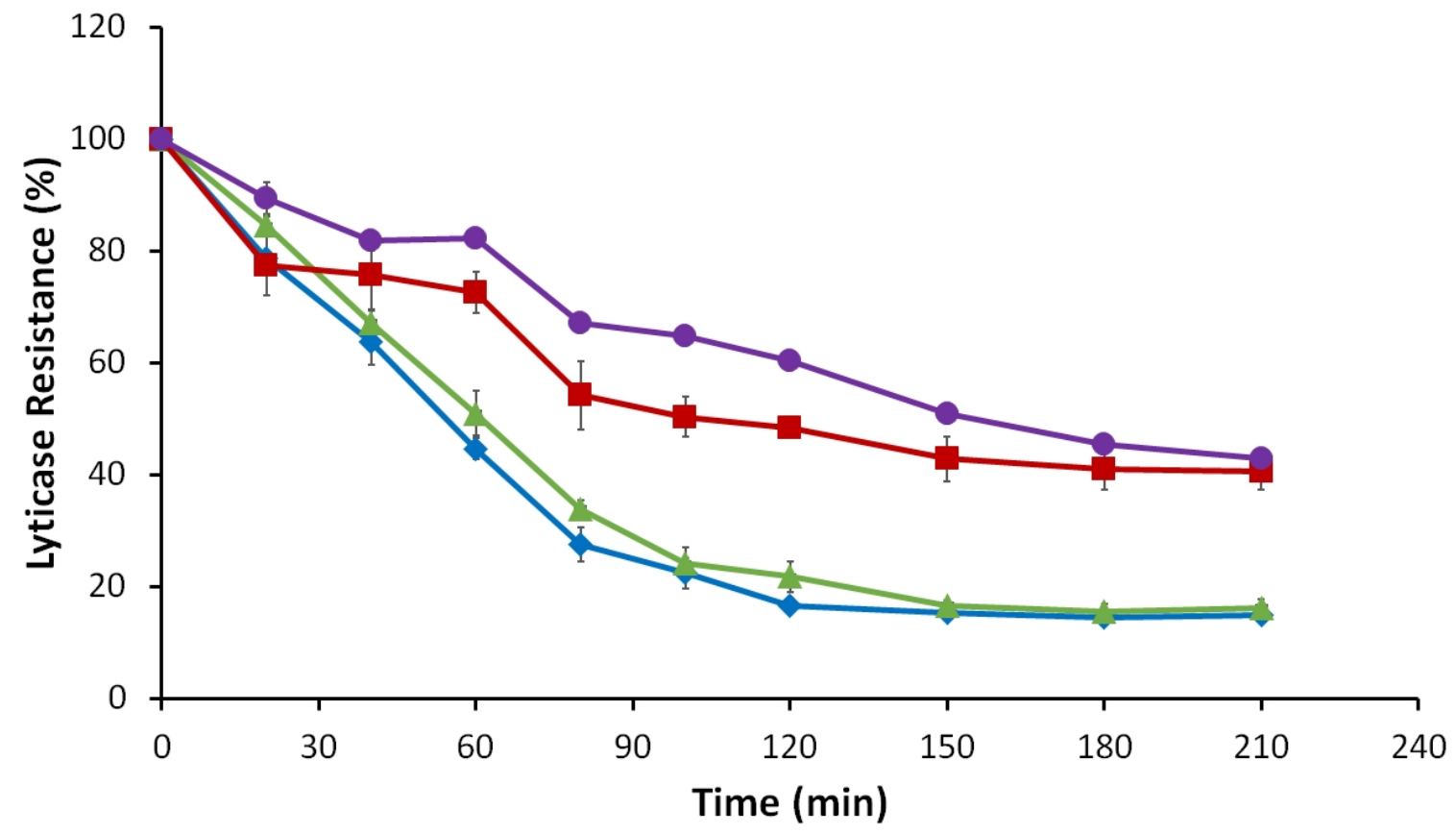

Figure 8. Lyticase susceptibilities of 905 and M8FE in the absence and presence of iron stress $(\diamond 905$ under control condition, $\mathbf{\square} 905$ under iron stress condition, $\triangle$ M8FE under control condition, $\bullet$ M8FE under iron stress condition). Lyticase susceptibility was assessed as the percent decrease in lyticase resistance (initial value $=100 \%$ ). 


\subsection{Transcriptomic Analysis Results}

\subsubsection{One-Color DNA-Microarray Analysis Results}

One-color microarray analyses were performed for M8FE and 905, under control and iron stress conditions. Samples for DNA-microarray analyses were withdrawn at an $\mathrm{OD}_{600}$ of about 1.0 $\left(5 \times 10^{7}\right.$ cells $\left./ \mathrm{mL}\right)$. The complete microarray data are available at the GEO repository under accession number GSE61317 [41]. Microarray result sets under control conditions were obtained by calculating the fold change of M8FE expression under control conditions versus the reference strain (905) expression under the same control conditions. It was found that 272 genes were upregulated and 287 genes were downregulated. Similarly, results under stress conditions were obtained by calculating the fold change of an M8FE expression under stress conditions versus the 905 expression under stress conditions. It was found that under stress conditions, only seven genes were upregulated and 31 genes were downregulated (Table 2). It was observed that the stress treatment decreased the number of differentially expressed genes in M8FE, compared to 905.

Table 2. Up- and downregulated gene numbers of various combinations of gene expression analysis sets according to GeneSpring GX 12.0 (Agilent Technologies) programme. FC indicates fold change.

\begin{tabular}{ccc}
\hline Analysis Set Name & Number of Upregulated Genes & Number of Downregulated Genes \\
\hline FC $([M 8 F E]$ vs. [905]) & 272 & 287 \\
\hline FC $([M 8 F E$ stress] vs. [905-stress] $)$ & 7 & 31 \\
\hline FC ([905 stress] vs. [905]) & 178 & 127 \\
\hline FC ([M8FE stress] vs. [M8FE]) & 213 & 208 \\
\hline
\end{tabular}

In addition to these two different sets of gene expression analysis, other combinations of gene expression analysis were also performed, such as; a fold change of 905 under stress conditions versus that of 905 under control conditions (Table 2). Finally, two analysis sets that involve the comparison of M8FE and 905 under control and iron stress conditions are discussed in this paper.

Up- and downregulated gene lists obtained from two analysis sets were clustered, the common and non-common gene lists were generated and the numbers of genes in these lists are shown as Venn diagrams (Figure 9) (GeneSpring GX 12.0, Agilent Technologies, Santa Clara, CA, USA).



Figure 9. Venn diagrams of common and non-common gene lists; $\mathrm{A}=\{\mathrm{UP}-\mathrm{FC}$ ([M8FE] vs. [905] under iron stress $\}, \mathrm{B}=\{\mathrm{DOWN}-\mathrm{FC}$ ([M8FE] vs. [905] under iron stress $\}, \mathrm{C}=\{\mathrm{UP}-\mathrm{FC}$ ([M8FE] vs. [905] under control cond. $\}, \mathrm{D}=\{\mathrm{DOWN}-\mathrm{FC}$ ([M8FE] vs. [905] under control cond. $\}$. FC indicates fold change.

The only gene that was upregulated in M8FE under both iron stress and control conditions was $B N A 3$ (Figure 9). Under iron stress conditions, BNA3 was upregulated by 2.8 -fold, and under control conditions, it was upregulated by 2.2-fold. This gene is responsible for the biosynthesis of nicotinic acid. 
The five genes that were downregulated in M8FE under both iron stress condition and control condition (with respect to the reference strain) were; PHO84, SPL2, UTP30, YIG1 and YPL245W. They were downregulated by 25.4-, 14.2-, 3.1-, 2.4- and 2.2-fold under iron stress conditions, and 70.5-, 10.2-, 2.4-, 2.8- and 2.2-fold under control conditions, respectively. It is known that the most downregulated gene of the group, $\mathrm{PHO} 84$, is a high-affinity inorganic phosphate (Pi) transporter and cells over-expressing PHO84 accumulate heavy metals $\left(\mathrm{Mn}^{2+}, \mathrm{Cu}^{2+}, \mathrm{Co}^{2+}\right)[42]$. Additionally, another common gene and the second most down-regulated gene of the mentioned group, SPL2, acts as a low-affinity phosphate transporter during phosphate limitation by targeting Pho87p to the vacuole. UTP30 is involved in the production of 18S rRNA. YIG1 plays a role in anaerobic glycerol production. YPL245W encodes a putative protein of unknown function [43]. As these five genes were downregulated in M8FE, compared to 905 under both conditions, their expression is most likely independent of the iron stress in the environment.

Transcriptome Profiles in the Absence of Iron Stress

M8FE expression levels with fold changes higher than 2, compared to 905 expression levels, were detected, and 272 genes were found to be upregulated in the absence of iron stress. Gene ontology analysis of those genes according to their biological processes have been performed using the Funspec tool [44] and the results are indicated in Table 3. Lists of all up- and down-regulated genes as folds of the reference strain in the absence of iron stress are provided in Supplemental Table S2.

Upregulated genes under control conditions have been clustered in several categories. Most of the genes were clustered in biological process and metabolic process categories. A significant number of them was clustered in glycogen and trehalose biosynthetic process categories and some of them in cellular response to oxidative stress category.

M8FE expression levels with fold changes higher than 2, compared to 905 expression levels, were detected, and 287 genes were found to be down-regulated in the absence of iron stress. Gene ontology analysis of those genes were performed according to their biological processes, by using the Funspec tool [44], and the results are shown in Table 3.

According to Funspec analysis results, most of the downregulated genes in M8FE were categorized under ribosome biogenesis-related groups. The ribosome biogenesis might be reduced by the mutant, possibly because of the high consumption of the cellular energy and the building blocks.

Figure 10 indicates the differentially-expressed genes in M8FE and their fold change values on the central carbon metabolic pathway. Considering glucose as the starting metabolite for metabolic pathways, it is transported by the help of some enzymes and transporters. High-affinity glucose transporter genes HXT6 and HXT7 were 6.6- and 8.1-fold upregulated, respectively, in M8FE under control conditions. MAL11, MAL12, MAL31 and MAL32, all responsible for maltose degradation to glucose, were 6.8-, 8.4-, 2.6- and 6.9-fold up-regulated, respectively, in M8FE under control conditions. These upregulated genes indicate that glucose can be maintained in the cytosol by the help of those changes in M8FE. The transported glucose can then be converted to Glucose-6P by hexokinase encoded by HXK1 and GLK1, which were 21.9- and 4.1-fold up-regulated, respectively, in M8FE, under control conditions. However, the levels of HXK2, the gene that represses the expression of HXK1 and GLK1, were not different from each other in M8FE and the reference strain. Glucose-6P would either then be converted into fructose 6-P or glucose 1-P, by either the glycolytic or the glycogen biosynthetic pathway, respectively. 
Table 3. Gene ontology analysis results of the upregulated and down-regulated genes in M8FE, in the absence of iron stress, according to their biological process, taken out of 2062 categories. For this analysis, Bonferroni correction [45] was performed and the $p$-value cut-off was selected as 0.01 (LSU: large subunit, SSU: small subunit).

\begin{tabular}{|c|c|c|}
\hline Category & $\begin{array}{l}\text { Number of Genes from the } \\
\text { Input Cluster in the Given } \\
\text { Category }\end{array}$ & $\begin{array}{l}\text { Number of Genes Total in the } \\
\text { Given Category }\end{array}$ \\
\hline \multicolumn{3}{|c|}{ Up-regulated genes } \\
\hline Biological process & 85 & 1203 \\
\hline Metabolic process & 39 & 425 \\
\hline Oxidation-reduction process & 29 & 272 \\
\hline Response to stress & 26 & 152 \\
\hline Carbohydrate metabolic process & 20 & 94 \\
\hline Cellular response to oxidative stress & 13 & 67 \\
\hline Glycolysis & 9 & 28 \\
\hline Glycogen biosynthetic process & 7 & 12 \\
\hline Trehalose biosynthetic process & 6 & 7 \\
\hline Maltose metabolic process & 6 & 11 \\
\hline \multicolumn{3}{|c|}{ Down-regulated genes } \\
\hline Ribosome biogenesis & 109 & 170 \\
\hline rRNA processing & 103 & 195 \\
\hline $\begin{array}{l}\text { Maturation of SSU-rRNA from tricistronic } \\
\text { rRNA transcript }\end{array}$ & 33 & 60 \\
\hline $\begin{array}{l}\text { Endonucleolytic cleavage in ITS1 to } \\
\text { separate SSU-rRNA from } 5.8 S \text { rRNA and } \\
\text { LSU-rRNA from tricistronic } \\
\text { rRNA transcript }\end{array}$ & 27 & 40 \\
\hline Ribosomal large subunit biogenesis & 24 & 37 \\
\hline $\begin{array}{l}\text { Endonucleolytic cleavage to generate } \\
\text { mature 5'-end of SSU-rRNA from } \\
\text { (SSU-rRNA, 5.8S rrna, LSU-rRNA) }\end{array}$ & 23 & 29 \\
\hline $\begin{array}{l}\text { Endonucleolytic cleavage in } 5^{\prime} \text {-ETS of } \\
\text { tricistronic rRNA transcript }\end{array}$ & 22 & 27 \\
\hline Ribosomal large subunit assembly & 19 & 38 \\
\hline tRNA processing & 17 & 80 \\
\hline Methylation & 16 & 71 \\
\hline Ribosomal small subunit biogenesis & 13 & 24 \\
\hline $\begin{array}{l}\text { Maturation of LSU-rRNA from tricistronic } \\
\text { rRNA transcript }\end{array}$ & 11 & 18 \\
\hline
\end{tabular}




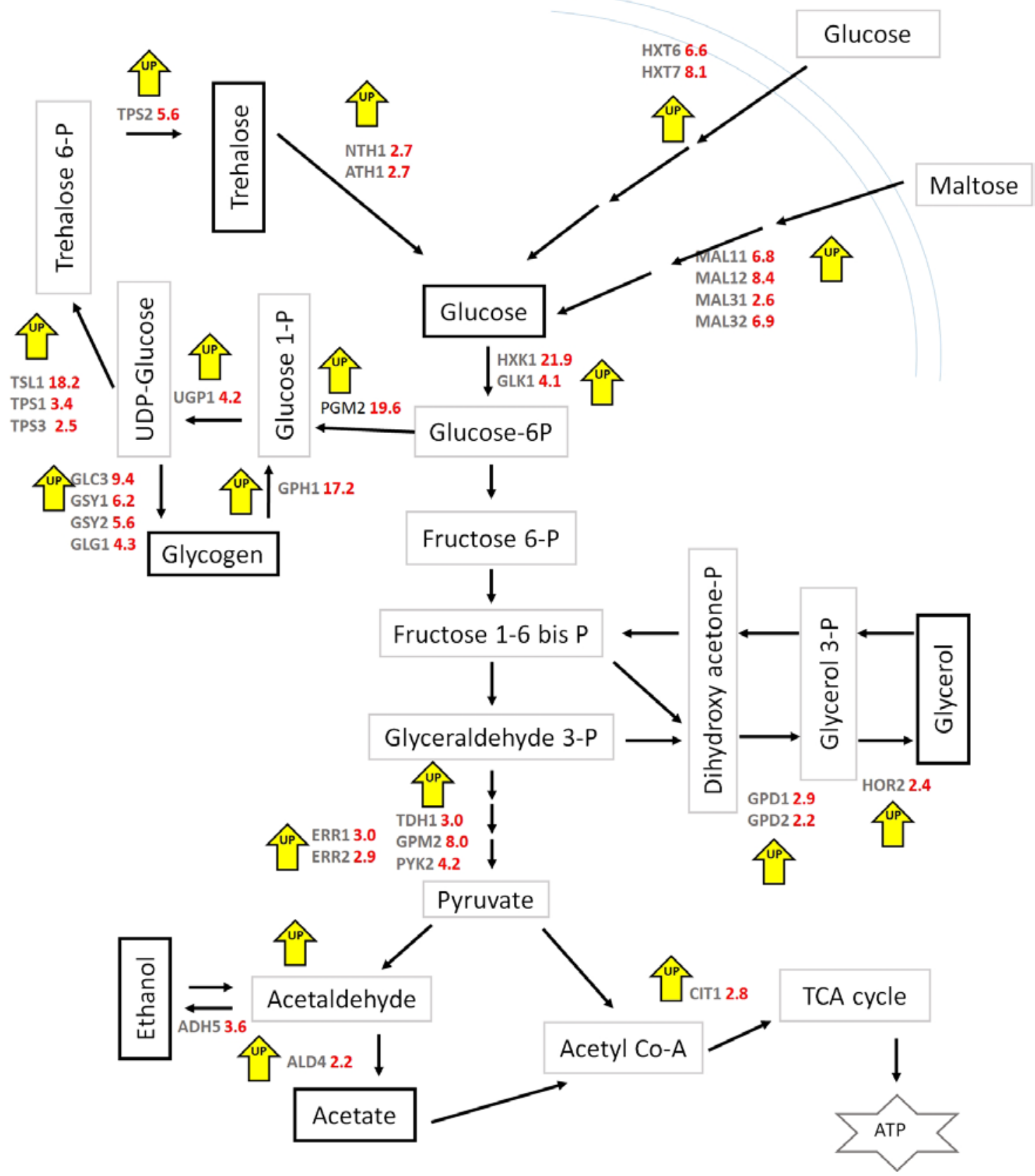

Figure 10. Upregulated genes in M8FE and their FC values as folds of 905 on the principal pathway of carbon metabolism (Figure was prepared by using the GeneSpring GX 12.0, Agilent Technologies-Wiki-pathway database [46]).

PGM2 that encodes phosphoglucomutase either converts glucose-1-phosphate to glucose-6-phosphate or conversely [47], which allows the switch between glycolysis or the glycogen biosynthesis pathway. According to the microarray results, PGM2 was 19.6-fold upregulated in M8FE under control conditions. Thus, the mutant seems to use this switch tightly between glycolysis and glycogen biosynthesis pathways. Glycogen and trehalose biosynthetic pathways seem to be more tightly regulated in M8FE than the reference strain, as many of the genes involved in these pathways were upregulated. Regarding the trehalose metabolic pathways, it was observed that not only were the genes related to trehalose biosynthesis, such as TSL1, upregulated in M8FE (by 18.2-fold of the reference strain), but also the trehalose degradation genes, such as NTH1 and ATH1 (both 2.7-fold upregulated in M8FE). These findings suggest that the trehalose metabolism of M8FE is active both 
in biosynthesis and degradation of trehalose, which most likely helps the strain to better adapt to the changes in the environment, including iron stress. Additionally, the genes related to glycerol biosynthesis, GPD1, GPD2 and HOR2, were also upregulated, supporting the glycerol production capacity of M8FE (Figure 10).

All genes indicated in Figure 10 were upregulated. Interestingly, there were no downregulated genes on any pathways which were categorized according to the Wiki-pathway database.

Transcriptome Profiles in the Presence of Iron Stress

Expression levels of M8FE with fold changes higher than 2, compared to 905 expression levels, were detected and seven genes were found to be upregulated. These genes were JLP1, YKL118W, FMO1, BNA3, AGP3, YML101C-A and LMO1 and they were upregulated by 4.50-, 3.66-, 13.26-, 32.81-, 32.6-, 2.45and 2.29-fold, respectively. According to these analysis results, 31 genes were downregulated. Like the upregulated genes, most of the downregulated genes are not characterized yet and cannot be clustered in a category. Three of the downregulated genes were phosphate-related genes: PHO84 (a high-affinity inorganic phosphate $(\mathrm{Pi})$ transporter), SPL2 (a down-regulator of low-affinity phosphate transport during phosphate limitation), and PHO92 (a posttranscriptional regulator of phosphate metabolism) were found to be downregulated by 25.49-, 14.24- and 12.85-fold, respectively (Supplemental Table S3).

\subsubsection{Validation of Microarray Results Using qRT-PCR}

Selected genes with significantly high levels of up- or downregulation in M8FE (HXK1, CTT1, HSP26, STR3, HSP104, HSP12 and PHO84) were used for the validation of the microarray results by qRT-PCR. According to Spearman's rank correlation test; calculated $p$ and rho values between qRT-PCR and microarray sets were 0.00007 and 0.86424 , respectively $[37,38]$. The qRT-PCR results were found to be in line with the microarray results, as indicated in Table 4.

Table 4. qRT-PCR values of M8FE as fold of the reference strain 905 and the corresponding microarray results normalized to $A C T 1$ as the log fold change of 905 for each selected gene.

\begin{tabular}{ccc}
\hline Gene Name & qRT-PCR Values of $\mathbf{M} 8 \mathbf{F E}$, as Fold of 905 & Microarray (Norm- $\boldsymbol{A C T 1}$ ) Log FC ([M8FE] vs. [905]) \\
\hline PHO84 & 0.18 & -6.17 \\
\hline HSP12 & 3.70 & 1.95 \\
\hline HSP104 & 4.62 & 1.96 \\
\hline STR3 & 4.35 & 2.96 \\
\hline CTT1 & 3.37 & 3.19 \\
\hline HSP26 & 7.94 & 3.26 \\
\hline HXK1 & 16.31 & 4.55 \\
\hline
\end{tabular}

\subsection{Mutations in M8FE Identified by Whole Genome Re-Sequencing Analysis}

The whole genomes of the mutant strains M8FE and the reference strain 905 were re-sequenced and 36 mutations were identified in M8FE, compared to 905. All mutations were found to be missense mutations, intragenic and transition substitutions, as a result of EMS mutagenesis [28] and were distributed among all chromosomes.

Five genes (SFI1, UTH1, EGT2, NOC3 and STU1) with missense mutations have biological functions related to cell division activity (Table 5). SNF6 and YRM1, two transcription factors with missense mutations in $M 8 F E$, are involved in chromatin remodelling and multidrug resistance, respectively [43].

The STT4 and VPS34 gene products show 26\% sequence identity and both play an essential role in phosphatidylinositol-mediated signalling and both were found to have missense mutations in M8FE (Table 5). The STT4 gene product also showed $27 \%$ sequence identity to the catalytic subunit of mammalian phosphatidylinositol (PI) 3-kinase [48]. 
Two genes, SSN2 and NUP2, with missense mutations in M8FE, are involved in the nuclear-transcribed mRNA catabolic process and one gene, ATX2, is related to metal homeostasis (Table 5).

Table 5. Selected mutations in M8FE compared to 905.

\begin{tabular}{|c|c|c|c|}
\hline Gene Name & Genetic Change & $\begin{array}{l}\text { Amino Acid } \\
\text { Substitution }\end{array}$ & Description \\
\hline \multicolumn{4}{|c|}{ Cell division } \\
\hline SFI1 & c. $2624 \mathrm{G}>\mathrm{A}$ & S875N & $\begin{array}{l}\text { Centrin (Cdc31p)-binding protein required for } \\
\text { SPB duplication. }\end{array}$ \\
\hline UTH1 & c. $436 \mathrm{~A}>\mathrm{G}$ & T146A & $\begin{array}{l}\text { Mitochondrial inner membrane protein; implicated in } \\
\text { cell wall biogenesis, the oxidative stress response, life } \\
\text { span during starvation and cell death. }\end{array}$ \\
\hline EGT2 & c. 1592 C > T & S531F & $\begin{array}{l}\text { Glycosylphosphatidylinositol (GPI)-anchored cell wall } \\
\text { endoglucanase; required for proper cell separation. }\end{array}$ \\
\hline NOC3 & c. $593 \mathrm{C}>\mathrm{T}$ & T198I & $\begin{array}{l}\text { Subunit of a nuclear complex with Noc2p and } \\
\text { pre-replicative complexes; required for pre-RC formation } \\
\text { and maintenance during DNA replication licensing. }\end{array}$ \\
\hline STU1 & c. $3416 \mathrm{C}>\mathrm{T}$ & T1139I & $\begin{array}{l}\text { Microtubule plus-end-tracking non-motor protein; } \\
\text { required for the structural integrity of the } \\
\text { mitotic spindle. }\end{array}$ \\
\hline \multicolumn{4}{|c|}{ Phosphatidylinositol-mediated signalling } \\
\hline VPS34 & c. $2131 \mathrm{G}>\mathrm{A}$ & $\mathrm{D} 711 \mathrm{~N}$ & $\begin{array}{l}\text { Phosphatidylinositol (PI) 3-kinase that synthesizes } \\
\text { PI-3-phosphate; forms membrane-associated signal } \\
\text { transduction complex with Vps15p to regulate } \\
\text { protein sorting. }\end{array}$ \\
\hline STT4 & c. $5341 \mathrm{C}>\mathrm{T}$ & P1781S & $\begin{array}{l}\text { Phosphatidylinositol-4-kinase; required for normal } \\
\text { vacuole morphology, cell wall integrity, and actin } \\
\text { cytoskeleton organization. }\end{array}$ \\
\hline \multicolumn{4}{|c|}{ Nuclear-transcribed mRNA catabolic process } \\
\hline SSN2 & c. $14 \mathrm{C}>\mathrm{T}$ & $\mathrm{A} 5 \mathrm{~V}$ & $\begin{array}{l}\text { Subunit of the RNA polymerase II mediator complex; } \\
\text { essential for transcriptional regulation. }\end{array}$ \\
\hline NUP2 & c. $627 \mathrm{~A}>\mathrm{G}$ & $\mathrm{I} 209 \mathrm{M}$ & $\begin{array}{l}\text { Nucleoporin involved in nucleocytoplasmic transport; } \\
\text { has a role in chromatin organization. }\end{array}$ \\
\hline \multicolumn{4}{|c|}{ Transcription factors } \\
\hline SNF6 & c. $940 \mathrm{G}>\mathrm{A}$ & E314K & $\begin{array}{l}\text { Subunit of the SWI/SNF chromatin remodelling complex; } \\
\text { involved in transcriptional regulation. }\end{array}$ \\
\hline YRM1 & c. $2251 \mathrm{G}>\mathrm{A}$ & E751K & $\begin{array}{l}\mathrm{Zn}(2) \text {-Cys(6) zinc finger transcription factor; activates } \\
\text { genes involved in multidrug resistance. }\end{array}$ \\
\hline \multicolumn{4}{|c|}{ Metal homeostasis } \\
\hline ATX2 & c. $61 \mathrm{G}>\mathrm{A}$ & G21R & $\begin{array}{l}\text { Golgi membrane protein involved in } \\
\text { manganese homeostasis. }\end{array}$ \\
\hline
\end{tabular}

\section{Discussion}

In this study, we have obtained an iron-resistant $S$. cerevisiae mutant, M8FE, which showed cross-resistance to other metals, such as chromium, nickel and cobalt. To gain insight into the cross-resistances of M8FE to the transition metals, it is necessary to know about the Earth's crust and habitat. Iron in the Earth's crust is most often found in the form of oxides, such as $\mathrm{Fe}_{2} \mathrm{O}_{3}$ hematite, $\mathrm{Fe}_{3} \mathrm{O}_{4}$ magnetite, $\mathrm{Fe}_{2} \mathrm{O}_{3} \cdot \mathrm{H}_{2} \mathrm{O}$ geothite, $\mathrm{Fe}_{2} \mathrm{O}_{3}$ maghemite and $\mathrm{Fe}_{2} \mathrm{O}_{3} \cdot \mathrm{H}_{2} \mathrm{O}$ lepidocrocite [4]. It can also be found in the form of minerals that have been categorized into several groups, such as pyrite, smaltite and chloanthite. Among these groups, iron-containing minerals generally co-exist with some other metals, predominantly $\mathrm{Co}$ and $\mathrm{Ni}$. This is because nickel and cobalt ions combine with iron and manganese hydroxides favourably [49]. However, in other cases, iron can also co-exist with $\mathrm{Cu}$ (chalcopyrite group), $\mathrm{Pb}$ (henryite), $\mathrm{Zn}$ (marmatite group) and $\mathrm{Au}$ (schirmerite group) [50]. Additionally, the main mineral source of chromium is the chromate " $\mathrm{FeCr}_{2} \mathrm{O}_{4}$ ". 
It is also known that cobalt stress induces iron uptake genes in S. cerevisiae, as observed in the case of iron starvation [51]. The resulting cobalt resistance found in the iron-resistant mutants $M 3 F E, M 5 F E$, $M 7 F E$ and M8FE was, therefore, not surprising. In a previous study of our group, a cobalt-resistant S. cerevisiae mutant obtained by evolutionary engineering was also found to be cross-resistant to several transition metals, such as iron, nickel, zinc and manganese, but not to copper and chromium ions [52]. Similarly, a nickel-resistant $S$. cerevisiae mutant obtained by evolutionary engineering was also cross-resistant to iron, cobalt, zinc and manganese [23].

It has been demonstrated in several studies that pre-conditioning enables cells to be more resistant to later lethal stresses. Sub-lethal doses of stress applications lead to protection and also cross-resistance to different stresses. Mild stress levels induce cells to be adapted so that cells enter an apoptotic-resistant state and increase resistance to stronger stress (a form of hormesis) [53]. Although the gained cross-resistance of M8FE to some transition metals like cobalt, chromium and nickel may seem like a pre-conditioning effect, it is important to note that the systematic evolutionary selection strategy with prolonged exposure to iron stress during many successive batch cultivations can be expected to yield a stronger and permanent cross-resistance against other stress types, for which the yeast cells may have similar resistance mechanisms or common molecular factors for resistance, than a simple pre-conditioning in a single batch cultivation.

Our microarray results revealed that $\mathrm{PHO} 84$ was the most downregulated gene in M8FE under both iron stress and control conditions. To our knowledge, there are not many reports in the literature that directly connect PHO84 to iron regulation: It has been reported previously that the PHO84 overexpression induced heavy metal $\left(\mathrm{Mn}^{2+}, \mathrm{Cu}^{2+}, \mathrm{Co}^{2+}\right.$ and $\left.\mathrm{Zn}^{2+}\right)$ accumulation in S. cerevisiae cells [42]. Additionally, when " $\triangle$ PHO84 S. cerevisiae" cells were challenged with high concentrations of zinc, cobalt and copper, they survived by preventing metal accumulation in the cell [54]. It has also been previously shown that high levels of cytosolic and non-vacuolar phosphate in pho80 mutants cause an increase in sodium and calcium levels and sensitivity to manganese, cobalt, zinc and copper. pho80 mutants cannot sense phosphate, thus phosphate uptake, storage and metabolism are disrupted. This also leads to iron starvation response in pho80 mutants, where the transcription factor Aft1p that responds to iron starvation becomes activated and the iron transport genes are upregulated in cells that contain high levels of phosphate. PHO84 transcript levels were also found to be increased by six-fold in pho80 mutants [55]. Our current study suggests that the mutant's iron resistance and even its cross-resistance to other transition metals might be related to the down-regulation of PHO84, according to the close connection between intracellular phosphate and iron homeostasis. Pho84p functions as an environmental $\mathrm{P}_{\mathrm{i}}$ level sensor and it is the main permease responsible for the uptake of phosphate into the cell. Pho84p also mediates rapid activation of the PKA (protein kinase A) pathway [56] similar to other transceptors that function both as a transporter and receptor. According to a recent study, the high-affinity iron transporter Ftr1p and high-affinity zinc transporter Zrt1p are also transceptors for the micronutrients iron and zinc in S. cerevisiae [57]. However, in M8FE, no gene expression changes were detected in ZRT1, while FTR1 was downregulated 2.16 times, as folds of the reference strain.

Jennings (1993) suggested that organisms evolved two major strategies to cope with the metal stress: "avoidance" and "sequestration" [16]. According to F-AAS results, it was found that M8FE had high reserves of iron in or on itself (most likely remaining from the evolutionary engineering selection experiment) under control conditions. According to those findings, it was estimated that M8FE used the sequestration mechanism to survive most probably by compartmentalization of its iron ions into vacuoles, as the RTN2 gene responsible for vesicle formation was upregulated in M8FE by 11.2-fold, in the absence of iron stress. Rtn2p is a reticulon protein member of the RTNLA (reticulon-like A) subfamily and is responsible for vesicle formation and membrane morphogenesis [58]. The upregulation of the RTN2 gene is most likely associated with the excess iron storage of M8FE in its vacuoles. It was also observed that, under iron stress conditions, M8FE prevented iron uptake more than the reference strain, indicating that M8FE might also be using the avoidance mechanism to survive under iron stress. Alternatively, M8FE might simply avoid further uptake of iron, as it 
is already loaded with iron under control conditions. Further studies would, thus, be necessary to clarify that.

According to the microarray results, many genes involved in oxidative stress response were upregulated in M8FE under control conditions. As the iron content of the mutant was also very high, this would lead to oxidative stress or damage in the cell, as reported previously $[59,60]$. However, intracellular ROS amounts of the mutant were lower than those of the reference strain, implying that the upregulated oxidative stress-related genes in M8FE most likely help reduce the intracellular oxidative levels. One of these upregulated genes, for example, is TSA2. Tsa2p cooperates with Tsa1p to remove reactive oxygen species. Tsa1p levels were shown to be highly correlated with iron toxicity levels in cells [61].

Based on our whole genome re-sequencing results, one of the reasons the iron stress-resistant mutant survived during the evolutionary selection strategy might be the missense mutations identified in ATX2, NUP2 and UTH1 genes, due to their close association with oxidative stress. It has been previously shown that the overexpression of the ATX2 gene causes cells to accumulate increased levels of manganese and suppresses oxygen toxicity in sod $1 \Delta$ mutants. Copper/zinc-dependent superoxide dismutase (Sod1p) plays a major role in the detoxification of oxygen free radicals, contributing to coping with the oxidative damage. Atx $2 p$ reverses oxidative damage of SOD1 deficiency. Atx $2 p$ localizes to the membrane of the Golgi-like vesicles of $S$. cerevisiae where manganese ions accumulate to maintain manganese homeostasis and trafficking. Deletion of the ATX2 gene decreases the available intracellular manganese levels. The ability of M8FE to cope with oxidative stress might be related to Atx2p. The phenotypic characteristics of $M 8 F E$, like high level of iron accumulation and cross-resistance to other transition metals, may indicate that ATX2 also functions in metal homeostasis [62].

Previously, it has been shown that a NUP2 deleted mutant of $S$. cerevisiae showed sensitivity to sodium arsenite $\left(\mathrm{NaAsO}_{2}\right)$ which generates oxidative stress in cells [63]. According to a global analysis of quantitative sensitivity profile of $S$. cerevisiae with homozygous diploid deletion of NUP2 under batch cultivation in continuous presence of $3 \mathrm{mM}$ hydrogen peroxide, data were hierarchically clustered within the group of increased oxidative stress resistance function [64].

It has been shown that $u t h 1 \varrho 0$ petite mutants have resistance to peroxides and sensitivity to superoxide, and the same effect has been observed in grande backgrounds. Additionally, multicopy plasmids showed increased resistance to superoxide and increased sensitivity to peroxides on wild-type cells. In aqueous, neutral $\mathrm{pH}$ solutions, $\mathrm{O}_{2}{ }^{-}$can behave as a reductant, and $\mathrm{H}_{2} \mathrm{O}_{2}$ as an oxidant for oxidized transition metal complexes of $\mathrm{Fe}^{3+}$ and $\mathrm{Cu}^{2+}$ so that these opposite phenotypes can be seen. The opposite effects of $\mathrm{O}_{2}{ }^{-}$and $\mathrm{H}_{2} \mathrm{O}_{2}$ on UTH1 may imply that Uth1p may be an Fe-binding protein and playing a role in iron homeostasis. It has been speculated that Uth1p serves as a molecular switch or sensor in the regulation of the oxidative-stress response [65].

UTH1 is also known to be associated with cell wall robustness and the mitochondrial protein levels, such as citrate synthase [66]. Our lyticase susceptibility assay results confirmed that the cell wall of M8FE was indeed more robust or resistant to degradation by lyticase, particularly in the presence of iron stress. Additionally, CIT2 gene encoding citrate synthase was also upregulated in M8FE.

Mutations in VPS34 and STT4, two genes encoding phosphatidylinositol kinases, also imply changes in signaling pathways and phosphate metabolism. Additionally, the mutation in YRM1, encoding a transcription factor involved in multidrug resistance [43], might be important for the iron resistance, as it is known for another pleiotropic drug resistance regulator, encoded by PDR1, where the expression of PDR1-regulated genes affects efflux and storage of transition metals [67].

ROS are natural by-products of respiration in mitochondria. When oxidative damage accumulates within mitochondria, autophagy of the organelle occurs selectively. This process, called mitophagy, is conserved from yeast to humans. Mitophagy may lead to several neurodegenerative diseases (e.g., Parkinson's) and aging $[68,69]$. It has been previously shown that mammalian mitochondrial rRNAs are degraded in response to oxidative stress [70]. Several mitochondrial degradation-related genes, such as ATG9, ATG1, ATG7, ATG29 and ICY2, were upregulated in M8FE in the absence of 
iron stress. Mitochondria provide cellular energy; however, whenever ATP is produced, intracellular ROS levels increase. To prevent high ROS levels and to keep its metabolic activities at base level in order to save energy, the mutant might be degrading its mitochondria. Another possible reason for the upregulation of mitochondria degradation-related genes can be the missense mutation on UTH1. As a mitochondrial outer-membrane protein, Uth1p plays a role in mitophagy. UTH1-deleted mutants showed a poorly-efficient mitochondria autophagy ability [68]. The missense mutation on UTH1 may lead to the upregulation of mitochondria degradation-related genes [65].

Acute iron overload or acute stresses can increase stress responsive intracellular ROS amounts. The intracellular ROS can induce programmed cell death (PCD) [71]. If the stress is high enough, it can lead to necroptosis or even necrosis. However, sub-acute stresses lead to a pre-condition that serves to protect against stress-induced PCD.

As well as acute stress, chronically stressed cells lead to iron overload, where iron accumulates in vesicles in some specific tissues (siderosis), like the brain, stomach and skin, and causes increased levels of ROS. This iron accumulation in vesicles is observed in many neurodegenerative diseases like Alzheimer's and Parkinson's. It is not known if those vesicles serve in a protective or a cell-damaging role [9].

The evolutionary engineering selection strategy that is used in this study may serve both as a sub-acute and sub-chronic stress selection strategy. The transcriptomic data of M8FE versus 905 under control conditions indicate that the mutant has already been exposed to iron stress during selection or, due to its high iron content, it is still under sub-acute stress levels regarding up-regulation of the stress responsive genes that generate protection against stress-induced PCD.

It is known that the "ribosome biogenesis" process requires high cellular energy [72]. It can therefore be suggested that the mutant prefers to save its energy as trehalose, rather than consuming it in ribosome biogenesis. Ribosome biogenesis is also related to cell division and growth. However, the mutant did not show any growth inhibition under both control and iron stress conditions [72].

Our transcriptomic analysis results revealed that the gene GPH1, responsible for glycogen degradation, was also upregulated by 17.2-fold. The glycogen degradation product "Glucose 1-P" can be used as a substrate for trehalose biosynthesis or it can be converted to "Glucose 6-P" by the help of phosphoglucomutase encoded by PGM2 (19.6-fold upregulated in M8FE). Glucose 6-P would then be either used in glycolysis or glycerol pathways. Glycerol is produced by S. cerevisiae to cope with the osmotic stress, to manage cytosolic phosphate levels or to maintain $\mathrm{NAD}^{+} / \mathrm{NADH}$ redox balance [73]. According to our physiological analysis results, high glycerol production of M8FE was remarkable, particularly under the $15 \mathrm{mM}\left(\mathrm{NH}_{4}\right)_{2} \mathrm{Fe}\left(\mathrm{SO}_{4}\right)_{2}$ stress condition. However, 905, under the same stress conditions, did not produce as much glycerol as M8FE. Thus, the glycerol production difference is most likely due to the robustness of $M 8 F E$ against the iron stress condition. However, the ethanol production of M8FE was not as much as the glycerol production, implying that the robust M8FE under iron stress conditions possibly shifted the ethanol production pathway to the glycerol production pathway.

The genes GPD1 and GPD2, which are responsible for the synthesis of glycerol 3-phophate dehydrogenase, were also upregulated in M8FE under control conditions. These results also support the increased glycerol biosynthesis observed in M8FE. To our knowledge, there have been no previous reports implying a relationship between metal stress and glycerol production.

According to the physiological analysis results, M8FE produced glycerol and trehalose at significantly higher levels than other metabolites. It has been previously reported that trehalose and glycerol synthesis and degradation genes were stress-induced; additionally, trehalose and glycerol were synthesized during the initial stages of stress treatment [74]. Consequently, it can be suggested that the high levels of trehalose and glycerol production and the upregulation of the related genes may help M8FE to overcome the high levels of iron stress. 


\section{Conclusions}

In this work, the complex molecular mechanisms and physiology of an iron-resistant S. cerevisiae mutant were investigated. The results revealed that the iron-resistant mutant had made significant changes in its energetic and storage metabolism, in its oxidative stress response and its iron storage behaviour. Additionally, it became cross-resistant to nickel, cobalt and chromium; and it had significantly lower intracellular ROS levels. The iron-resistant evolved strain seemed to be prepared for the iron stress by upregulating its oxidative stress response genes, downregulating its ribosome biogenesis genes and tightly controlling its reserve carbohydrate biosynthesis and degradation-related genes.

The gene expression data provided by microarray analysis and the whole genome re-sequencing results are generally in line with the growth physiology data of the mutant and the reference strain. Microarray analysis enabled a system-level investigation of the changes in the mutant at the transcriptomic level. Additionally, comparative whole-genome sequencing analysis enabled genome level identification of the mutant in order to endow highlighted genes to other organisms for further studies as evolutionary engineering suggests. The results suggest that the potential role of phosphate transporters and metabolism, cell wall integrity and the multidrug transporters in iron resistance are yet to be investigated in detail.

For a better understanding of the complex molecular mechanism of iron resistance in S. cerevisiae further investigations, including functional genomic and proteomic analyses, are necessary. These findings will help elucidate the complex role of iron and other metals in microbial biodiversity, health and nutrition.

Supplementary Materials: The following are available online at http://www.mdpi.com/2076-2607/8/1/43/s1. Figure S1: Survival rates of the reference strain 905 and the EMS-mutagenized initial population 906 upon increasing iron stress conditions, Table S1: Cobalt contents of M8FE and the reference strain 905 upon $2.5 \mathrm{mM}$ $\mathrm{CoCl}_{2}$ pulse stress treatment, as determined by F-AAS (wavelength and slit width 240.7 and $0.2 \mathrm{~nm}$, respectively), Table S2: List of 272 up- and 287 down-regulated genes in M8FE in the absence of iron stress, as folds of the reference strain, Table S3: List of 31 down-regulated genes in M8FE in the presence of $15 \mathrm{mM}\left(\mathrm{NH}_{4}\right)_{2} \mathrm{Fe}\left(\mathrm{SO}_{4}\right)_{2}$ as the iron stress factor, as folds of the reference strain. The complete microarray data is available at the GEO repository under the accession number GSE61317 [41]. Whole-genome re-sequencing data have been deposited in the NCBI Sequence Read Archive (SRA) under BioProject PRJNA575869 at https://www.ncbi.nlm.nih.gov/sra/PRJNA575869.

Author Contributions: Z.P.Ç. conceived the study, designed the project and revised the manuscript. B.G.B. contributed to the project, conducted the experiments, analysed the data and wrote the manuscript. Ü.Y. and C.A. contributed to the experiments and the analysis. A.T. contributed to the experiments and to the writing of the revised version of the manuscript. H.I.K. carried out the microarray analysis. C.H. carried out the genome data analysis. All authors have read and agreed to the published version of the manuscript.

Funding: This research was funded by Scientific and Technological Research Council of Turkey, TUBITAK, as a COST Action project CM0902 with a project number of 109T638 and also supported by Istanbul Technical University Scientific Research Funds as BAP projects with the project numbers: 36389 and 36128.

Acknowledgments: The CEN.PK 113-7D (MATa, MAL2-8c, SUC2) Saccharomyces cerevisiae strain was kindly provided by Jean Marie François and Laurent Benbadis from Toulouse University (France). We thank Sema Gündüz and Süleyman Akman for F-AAS analysis (Department of Chemistry, Istanbul Technical University). We also thank Cihan Erdinç Gülsev and Nazlı Kocaefe for technical assistance with the whole genome re-sequencing experiments.

Conflicts of Interest: The authors declare no conflict of interest.

\section{References}

1. Wessling-Resnick, M. Biochemistry of iron uptake. Crit. Rev. Biochem. Mol. Biol. 1999, 34, 285-314. [CrossRef] [PubMed]

2. Aisen, P.; Enns, C.; Wessling-Resnick, M. Chemistry and biology of eukaryotic iron metabolism. Int. J. Biochem. Cell Biol. 2001, 33, 940-959. [CrossRef]

3. Sheftel, A.D.; Mason, A.B.; Ponka, P. The long history of iron in the Universe and in health and disease. Biochim. Biophys. Acta Gen. Subj. 2012, 1820, 161-187. [CrossRef] [PubMed]

4. Silver, J. Chemistry of Iron, 1st ed.; Chapman \& Hall: New Delhi, India, 1993.

5. Crichton, R.R. Biological Inorganic Chemistry, 2nd ed.; Elsevier: Amsterdam, The Netherlands, 2012. 
6. Valko, M.; Rhodes, C.J.; Moncol, J.; Izakovic, M.; Mazur, M. Free radicals, metals and antioxidants in oxidative stress-induced cancer. Chem. Biol. Interact. 2006, 160, 1-40. [CrossRef] [PubMed]

7. Costa, V.; Moradas-Ferreira, P. Oxidative stress and signal transduction in Saccharomyces cerevisiae: Insights into ageing, apoptosis and diseases. Mol. Asp. Med. 2001, 22, 217-246. [CrossRef]

8. Bleackley, M.R.; Macgillivray, R.T.A. Transition metal homeostasis: From yeast to human disease. Biometals 2011, 24, 785-809. [CrossRef]

9. Eid, R.; Arab, N.T.T.; Greenwood, M.T. Iron mediated toxicity and programmed cell death: A review and a re-examination of existing paradigms. Biochim. Biophys. Acta Mol. Cell Res. 2017, 1864, 399-430. [CrossRef]

10. Koechler, S.; Farasin, J.; Cleiss-Arnold, J.; Arsene-Ploetze, F. Toxic metal resistance in biofilms: Diversity of microbial responses and their evolution. Res. Microbiol. 2015, 166, 764-773. [CrossRef]

11. Caviccholi, R.; Ripple, W.J.; Timmis, K.N.; Azam, F.; Bakken, L.R.; Baylis, M.; Behrenfeld, M.J.; Boeitus, A.; Boyd, P.W.; Classen, A.T.; et al. Scientist' warning to humanity: Microorganisms and climate change. Nat. Rev. Microbiol. 2019, 17, 569-586. [CrossRef]

12. Kyyaly, M.A.; Powell, C.; Ramadan, E. Preparation of iron-enriched baker's yeast and its efficiency in recovery of rats from dietary iron deficiency. Nutrition 2015, 31, 1155-1164. [CrossRef]

13. Reed, S.; Hadar, N.; Raymond, P.G.; Omry, K.; Elay, T. Characterizing the gut (Gallus gallus) microbiota following the consumption of an iron biofortified Rwandan cream seeded carioca (Phaseolus Vulgaris L.) bean-based diet. PLoS ONE 2017, 12, 1-15. [CrossRef] [PubMed]

14. Parmanand, B.A.; Kellingray, L.; Le Gall, G.; Basit, A.W.; Fairweather-Tat, S.; Narbad, A. A decrease in iron availability to human gut microbiome reduces the growth of potentially pathogenic gut bacteria; an in vitro colonic fermentation study. J. Nutr. Biochem. 2019, 67, 20-27. [CrossRef] [PubMed]

15. Askwith, C.C.; de Silva, D.; Kaplan, J. Molecular biology of iron acquisition in Saccharomyces cerevisiae. Mol. Microbiol. 1996, 20, 27-34. [CrossRef] [PubMed]

16. Jennings, D.H. Stress Tolerance of Fungi, 10th ed.; Marcel Dekker: New York, NY, USA, 1993.

17. Alberts, B.; Johnson, A.; Lewis, J.; Raff, M.; Roberts, K.; Walter, P. Molecular Biology of the Cell, 4th ed.; Garland Science: New York, NY, USA, 2002.

18. Dickinson, J.R.; Schweizer, M. The Metabolism and Molecular Physiology of Saccharomyces Cerevisiae, 2nd ed.; CRC Press: Boca Raton, FL, USA, 2004.

19. Chen, X.-Z. Yeast SMF1 Mediates H+-coupled iron uptake with concomitant uncoupled cation currents. J. Biol. Chem. 1999, 274, 35089-35094. [CrossRef] [PubMed]

20. Cakar, Z.P.; Seker, U.O.S.; Tamerler, C.; Sonderegger, M.; Sauer, U. Evolutionary engineering of multiple-stress resistant Saccharomyces cerevisiae. FEMS Yeast Res. 2005, 5, 569-578. [CrossRef] [PubMed]

21. Cakar, Z.P.; Alkim, C.; Turanli, B.; Tokman, N.; Akman, S.; Sarikaya, M.; Tamerler, C.; Benbadis, L.; François, J.M. Isolation of cobalt hyper-resistant mutants of Saccharomyces cerevisiae by in vivo evolutionary engineering approach. J. Biotechnol. 2009, 143, 130-138. [CrossRef]

22. Sen, M.; Yılmaz, U.; Baysal, A.; Akman, S.; Cakar, Z.P. In vivo evolutionary engineering of a boron-resistant bacterium: Bacillus boroniphilus. Antonie Leeuwenhoek 2011, 99, 825-835. [CrossRef]

23. Küçükgöze, G.; Alkım, C.; Yılmaz, Ü.; Kısakesen, H.İ.; Gündüz, S.; Akman, S.; Çakar, Z.P. Evolutionary engineering and transcriptomic analysis of nickel-resistant Saccharomyces cerevisiae. FEMS Yeast Res. 2013, 13, 731-746. [CrossRef]

24. Turanl1-Yıldız, B.; Benbadis, L.; Alkım, C.; Sezgin, T.; Akşit, A.; Gökçe, A.; Öztürk, Y.; Baykal, A.T.; Çakar, Z.P.; François, J.M. In vivo evolutionary engineering for ethanol-tolerance of Saccharomyces cerevisiae haploid cells triggers diploidization. J. Biosci. Bioeng. 2017, 124, 309-318. [CrossRef]

25. Arslan, M.; Holyavkin, C.; Kısakesen, H.İ; Topaloğlu, A.; Sürmeli, Y.; Çakar, Z.P. Physiological and transcriptomic analysis of a chronologically long-lived Saccharomyces cerevisiae strain obtained by evolutionary engineering. Mol. Biotechnol. 2018, 60, 468-484. [CrossRef]

26. Hacısalihoğlu, B.; Holyavkin, C.; Topaloğlu, A.; Kısakesen, H.İ.; Çakar, Z.P. Genomic and transcriptomic analysis of a coniferyl aldehyde-resistant Saccharomyces cerevisiae strain obtained by evolutionary engineering. FEMS Yeast Res. 2019, 19, foz021. [CrossRef] [PubMed]

27. Sürmeli, Y.; Holyavkin, C.; Topaloğlu, A.; Arslan, M.; Kısakesen, H.İ.; Çakar, Z.P. Evolutionary engineering and molecular characterization of a caffeine-resistant Saccharomyces cerevisiae strain. World J. Microbiol. Biotechnol. 2019, 35, 183. [CrossRef] [PubMed]

28. Lawrence, C.W. Classical mutagenesis techniques. Methods Enzymol. 1991, 194, 273-278. [PubMed] 
29. Russek, E.; Colwell, R.R. Computation of most probable numbers. Appl. Environ. Microbiol. 1983, 45, $1646-1650$. [PubMed]

30. Lindquist, J. The MPN Method. Available online: http://www.jlindquist.com/generalmicro/102dil3.html (accessed on 1 September 2019).

31. Pereira, M.D.; Eleutherio, E.C.; Panek, D. Acquisition of tolerance against oxidative damage in Saccharomyces cerevisiae. BMC Microbiol. 2001, 1, 11. [CrossRef] [PubMed]

32. Kommuguri, U.N.; Bodiga, S.; Sankuru, S.; Bodiga, V.L. Copper deprivation modulates CTR1 and CUP1 expression and enhances cisplatin cytotoxicity in Saccharomyces cerevisiae. J. Trace Elem. Med. Biol. 2012, 26, 13-19. [CrossRef] [PubMed]

33. Kuranda, K.; Leberre, V.; Sokol, S.; Palamarczyk, G.; François, J. Investigating the caffeine effects in the yeast Saccharomyces cerevisiae brings new insights into the connection between TOR, PKC and Ras/cAMP signaling pathways. Mol. Microbiol. 2006, 61, 1147-1166. [CrossRef] [PubMed]

34. Benjamini, Y.; Hochberg, Y. Controlling the false discovery rate: A practical and powerful approach to multiple testing. J. R. Stat. Soc. 1995, 57, 289-300. [CrossRef]

35. Rozen, S.; Skaletsky, H. Primer3 on the WWW for general users and for biologist programmers. Bioinforma. Methods Protoc. 1999, 132, 365-386.

36. Livak, K.J.; Schmittgen, T.D. Analysis of relative gene expression data using real-time quantitative PCR and the 2(-Delta Delta C(T)) Method. Methods 2001, 25, 402-408. [CrossRef]

37. Myles, H.; Wolfe, D.A. Nonparametric Statistical Methods; John Wiley \& Sons.: New York, NY, USA, 1973.

38. Best, D.J.; Roberts, D.E. Algorithm AS 89: The upper tail probabilities of Spearman's rho. Appl. Stat. 1975, 24, 377-379. [CrossRef]

39. R: A Language and Environment for Statistical, Vienna Austria. Available online: https://www.r-project.org/ (accessed on 20 September 2019).

40. François, J.; Parrou, J. Reserve carbohydrates metabolism in the yeast Saccharomyces cerevisiae. FEMS Microbiol. Rev. 2001, 25, 125-145. [CrossRef] [PubMed]

41. Balaban, B.G.; Alkım, C.; Yılmaz, U.; Kısakesen, H.I.; Cakar, Z.P. NCBI GEO Query DataSets for GSE61317. Available online: http://www.ncbi.nlm.nih.gov/geo/query/acc.cgi?acc=GSE61317 (accessed on 11 September 2014).

42. Ofiteru, A.M.; Ruta, L.L.; Rotaru, C.; Dumitru, I.; Ene, C.D.; Neagoe, A.; Farcasanu, I.C. Overexpression of the $\mathrm{PHO} 84$ gene causes heavy metal accumulation and induces Ire1p-dependent unfolded protein response in Saccharomyces cerevisiae cells. Appl. Microbiol. Biotechnol. 2012, 94, 425-435. [CrossRef] [PubMed]

43. Saccharomyces Genome Database. Available online: http://www.yeastgenome.org/ (accessed on 20 September 2018).

44. Robinson, M.D.; Grigull, J.; Mohammad, N.; Hughes, T.R. Robinson FunSpec: A Web-Based Cluster Interpreter for Yeast. Available online: http://funspec.med.utoronto.ca/ (accessed on 7 March 2013).

45. Bonferroni, C.E. Teoria statistica delle classi e calcolo delle probabilitá. Pubbl. Ist. Super. Sci. Econ. Commer. Firenze 1936, 8, 3-62.

46. Slenter, D.N.; Kutmon, M.; Hanspers, K.; Riutta, A.; Windsor, J.; Nunes, N.; Mélius, J.; Cirillo, E.; Coort, S.L.; DIgles, D.; et al. WikiPathways: A multifaceted pathway database bridging metabolomics to other omics research. Nucleic Acids Res. 2018, 46, D661-D667. [CrossRef]

47. Rai, M. Advances in Fungal Biotechnology; I.K. International Publishing House: New Delhi, India, 2009.

48. Yoshida, S.; Ohya, Y.; Goebl, M.; Nakano, A.; Anraku, Y. A novel gene, STT4, encodes a phosphatidylinositol 4-kinase in the PKCl protein kinase pathway of Saccharomyces cerevisiae. J. Biol. Chem. 1994, 269, 1166-1172.

49. Barałkiewicz, D.; Siepak, J. Chromium, nickel and cobalt in environmental samples and existing legal norms. Polish J. Environ. Stud. 1999, 8, 201-208.

50. Collins, J.H. On mineral classification. Mineral. Mag. J. Mineral. Socity Gt. Britain Irel. 1878, II, 65-81. [CrossRef]

51. Stadler, J.A.; Schweyen, R.J. The yeast iron regulon is induced upon cobalt stress and crucial for cobalt tolerance. J. Biol. Chem. 2002, 277, 39649-39654. [CrossRef] 
52. Alkim, C.; Benbadis, L.; Yilmaz, U.; Cakar, Z.P.; François, J.M. Mechanisms other than activation of the iron regulon account for the hyper-resistance to cobalt of a Saccharomyces cerevisiae strain obtained by evolutionary engineering. Metallomics 2013, 5, 1043-1060. [CrossRef]

53. Clapp, C.; Portt, L.; Khoury, C.; Sheibani, S.; Eid, R.; Greenwood, M.; Vali, H.; Mandato, C.A.; Greenwood, M.T. Untangling the roles of anti-apoptosis in regulating programmed cell death using humanized yeast cells. Front. Oncol. 2012, 59, 1-17. [CrossRef] [PubMed]

54. Jensen, L.T.; Ajua-Alemanji, M.; Culotta, V.C. The Saccharomyces cerevisiae high affinity phosphate transporter encoded by PHO84 also functions in manganese homeostasis. J. Biol. Chem. 2003, 278, 42036-42040. [CrossRef] [PubMed]

55. Rosenfeld, L.; Reddi, A.R.; Leung, E.; Aranda, K.; Jensen, L.T.; Culotta, V.C. The effect of phosphate accumulation on metal ion homeostasis in Saccharomyces cerevisiae. J. Biol. Inorg. Chem. 2010, 15, 1051-1062. [CrossRef] [PubMed]

56. Samyn, D.R.; Ruiz-Pávon, L.; Andersson, M.R.; Popova, Y.; Thevelein, J.M.; Persson, B.L. Mutational analysis of putative phosphate- and proton-binding sites in the Saccharomyces cerevisiae Pho84 phosphate:H + transceptor and its effect on signalling to the PKA and PHO pathways. Biochem. J. 2012, 445, 413-422. [CrossRef]

57. Schothorst, J.; Van Zeebroeck, G.; Thevelein, J. Identification of Ftr1 and Zrt1 as iron and zinc micronutrient transceptors for activation of the PKA pathway in Saccharomyces cerevisiae. Microb. Cell 2017, 4, 74-89. [CrossRef]

58. Yang, Y.S.; Strittmatter, S.M. The reticulons: A family of proteins with diverse functions. Genome Biol. 2007, 8, 234. [CrossRef]

59. Touati, D. Iron and oxidative stress in bacteria. Arch. Biochem. Biophys. 2000, 373, 1-6. [CrossRef]

60. Valko, M.; Morris, H.; Cronin, M.T.D. Metals, toxicity and oxidative stress. Curr. Med. Chem. 2005, 12, 1161-1208. [CrossRef]

61. Lin, H.; Li, L.; Jia, X.; Ward, D.M.; Kaplan, J. Genetic and biochemical analysis of high iron toxicity in yeast: Iron toxicity is due to the accumulation of cytosolic iron and occurs under both aerobic and anaerobic conditions. J. Biol. Chem. 2011, 286, 3851-3862. [CrossRef]

62. Lin, S.J.; Culotta, V.C. Suppression of oxidative damage by Saccharomyces cerevisiae ATX2, which encodes a manganese-trafficking protein that localizes to Golgi-like vesicles. Mol. Cell. Biol. 1996, 16, 6303-6312. [CrossRef]

63. Zhou, X.; Arita, A.; Ellen, T.P.; Liu, X.; Bai, J.; Rooney, J.P.; Kurtz, A.D.; Klein, C.B.; Dai, W.; Begley, T.J.; et al. A genome-wide screen in Saccharomyces cerevisiae reveals pathways affected by arsenic toxicity. Genomics 2009, 94, 294-307. [CrossRef] [PubMed]

64. Brown, J.A.; Sherlock, G.; Myers, C.L.; Burrows, N.M.; Deng, C.; Wu, H.I.; McCann, K.E.; Troyanskaya, O.G.; Brown, J.M. Global analysis of gene function in yeast by quantitative phenotypic profiling. Mol. Syst. Biol. 2006. [CrossRef] [PubMed]

65. Bandara, P.D.S.; Flattery-O'Brien, J.A.; Grant, C.M.; Dawes, I.W. Involvement of the Saccharomyces cerevisiae UTH1 gene in the oxidative-stress response. Curr. Genet. 1998, 34, 259-268. [CrossRef] [PubMed]

66. Ritch, J.J.; Davidson, S.M.; Sheehan, J.J.; Austriaco, O.P. The Saccharomyces SUN gene, UTH1, is involved in cell wall biogenesis. FEMS Yeast Res. 2010, 10, 168-176. [CrossRef] [PubMed]

67. Tuttle, M.S.; Radisky, D.; Li, L.; Kaplan, J. A dominant allele of PDR1 alters transition metal resistance in yeast. J. Biol. Chem. 2003, 278, 1273-1280. [CrossRef] [PubMed]

68. Lemasters, J.J. Selective mitochondrial autophagy, or mitophagy, as a targeted defense against oxidative stress, mitochondrial dysfunction, and aging. Rejuvenation Res. 2005, 8, 3-5. [CrossRef] [PubMed]

69. Camougrand, N.; Bhatia-kis, I. Mitophagy in yeast: Actors and physiological roles. FEMS Yeast Res. 2010, 10, 1023-1034.

70. Crawford, D.R.; Wang, Y.; Schools, G.P.; Kochheiser, J.; Davies, K.J.A. Down-regulation of mammalian mitochondrial RNAs during oxidative stress. Free Radic. Biol. Med. 1997, 22, 551-559. [CrossRef]

71. Carmona-Gutierrez, D.; Bauer, M.A.; Zimmermann, A.; Aguilera, A.; Austriaco, N.; Ayscough, K.; Balzan, R.; Bar-Nun, S.; Barrientos, A.; Belenky, P. Guidelines and recommendations on yeast cell death nomenclature. Microb. Cell 2018, 5, 4-31. [CrossRef] 
72. Thomson, E.; Ferreira-Cerca, S.; Hurt, E. Eukaryotic ribosome biogenesis at a glance. J. Cell Sci. 2013, 126, 4815-4821. [CrossRef]

73. Scanes, K.T.; Hohmann, S.; Prior, B.A. Glycerol production by the yeast Saccharomyces cerevisiae and its relevance to wine: A review. S. Afr. J. Enol. Vitic. 1998, 19, 17-24. [CrossRef]

74. Li, L.; Ye, Y.; Pan, L.; Zhu, Y.; Zheng, S.; Lin, Y. The induction of trehalose and glycerol in Saccharomyces cerevisiae in response to various stresses. Biochem. Biophys. Res. Commun. 2009, 387, 778-783. [CrossRef] [PubMed]

(C) 2019 by the authors. Licensee MDPI, Basel, Switzerland. This article is an open access article distributed under the terms and conditions of the Creative Commons Attribution (CC BY) license (http://creativecommons.org/licenses/by/4.0/). 